\title{
Benthic Ecoregionalization based on echinoid fauna of the Southern Ocean supports current proposals of Antarctic Marine Protected Areas under IPCC scenarios of climate change
}

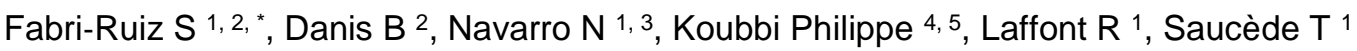

\author{
${ }^{1}$ Biogéosciences, UMR CNRS/EPHE 6282 Université Bourgogne Franche-Comté 6 Boulevard Gabriel \\ 21000 Dijon, France \\ ${ }^{2}$ Laboratoire de Biologie Marine Université Libre de Bruxelles 50 avenue FD RooseveltB-1050 \\ Brussels, Belgium \\ ${ }^{3}$ EPHE ,PSL University 4-14 rue Ferrus 75014 Paris ,France \\ 4 UFR 918 Terre Environnement et Biodiversité Sorbonne Université 4, place Jussieu 75252 Paris \\ Cedex ,France \\ 5 IFREMER ,Centre Manche mer du Nord. Laboratoire HMMN 150 quai Gambetta 62321 Boulogne-sur- \\ Mer ,France \\ *Corresponding author : S. Fabri-Ruiz, email address : salome.fabriruiz@gmail.com
}

\begin{abstract}
:
The Southern Ocean (SO) is among the regions on Earth that are undergoing regionally the fastest environmental changes. The unique ecological features of its marine life make it particularly vulnerable to the multiple effects of climate change. A network of Marine Protected Areas (MPAs) has started to be implemented in the SO to protect marine ecosystems. However, considering future predictions of the Intergovernmental Panel on Climate Change (IPCC), the relevance of current, static, MPAs may be questioned under future scenarios. In this context, the ecoregionalization approach can prove promising in identifying well-delimited regions of common species composition and environmental settings. These so-called ecoregions are expected to show similar biotic responses to environmental changes and can be used to define priority areas for the designation of new MPAs and the update of their current delimitation. In the present work, a benthic ecoregionalization of the entire SO is proposed for the first time based on abiotic environmental parameters and the distribution of echinoid fauna, a diversified and common member of Antarctic benthic ecosystems. A novel two-step approach was developed combining species distribution modelling with Random Forest and Gaussian Mixture modelling from species probabilities to define current ecoregions and predict future ecoregions under IPCC scenarios RCP 4.5 and 8.5. The ecological representativity of current and proposed MPAs of the SO are discussed with regards to the modeled benthic ecoregions. Twelve benthic ecoregions were determined under Present conditions, they are representative of major biogeographic patterns already described. Our results show that the most dramatic changes can be expected along the Antarctic Peninsula, in East Antarctica and the sub-Antarctic islands under both IPCC scenarios. Our results advocate for a dynamic definition of MPAs, they also argue for improving the representativity of Antarctic ecoregions in proposed MPAs and support current proposals of CCAMLR for the creation of Antarctic MPAs.
\end{abstract}


Keywords : climate change, echinoids, ecological niche modelling, ecoregionalization, Marine Protected Areas 


\section{Introduction}

Polar seas are among the regions in the world that are undergoing climate change at the fastest pace (Convey et al., 2009; Turner et al., 2009; Turner \& Comiso, 2017). In the Southern Ocean (SO), which is a wide expanse of waters circling the globe without interruption from the Antarctic

This article is protected by copyright. All rights reserved 
continent to about $45^{\circ} \mathrm{S}$ latitude, the multiple and synergetic effects of climate change lead to sea water temperature increase, salinity decrease, sea water acidification, UV-B radiation increase, changes in sea ice regime, ice shelves collapse and coastal glacier retreat (Etourneau et al., 2019; Fabry, McClintock, Mathis, \& Grebmeier, 2009; Gutt et al., 2015; Menezes, Macdonald, \& Schatzman, 2017; Reygondeau \& Huettmann, 2014). Deep waters are also impacted by environmental changes. A large part of the water column has started to warm south of the subAntarctic front, including Antarctic Bottom Water formed around the Antarctic edge. Although these changes are not uniform around the Antarctic (eg, Antarctic Peninsula vs Ross Sea). These modifications in the downwelling of cold and dense waters would have a profound effect on climate system as it is a central part of the thermohaline circulation (Purkey \& Johnson, 2013; Schmidtko, Heywood, Thompson, \& Aoki, 2014). Future scenarios predict a southward shift of major marine fronts associated with an intensification of surface water stratification (Bracegirdle et al., 2013; Meijers et al., 2012; Sen Gupta et al., 2009).

Marine life of the SO displays unique physiological characteristics and life history traits including high levels of endemism (Griffiths, Barnes, \& Linse, 2009; Kaiser et al., 2013; Saucède, Pierrat, \& David, 2014), adaptations to seasonally subzero water temperatures with high sensitivity to increase in temperature due to their narrow thermal niche (Cheng \& William, 2007; Peck, 2016, 2018; Portner, Peck, \& Somero, 2007) and brooding (David \& Mooi, 1990; Hunter \& Halanych, 2008; Sewell \& Hofmann, 2011), which make it particularly vulnerable to environmental changes (Guillaumot et al., 2018; Ingels et al., 2012; Lohrer, Cummings, \& Thrush, 2013; Peck, 2005; Peck, Morley, \& Clark, 2010; Peck, Webb, \& Bailey, 2004). Multiple impacts of climate change have been documented on SO benthic marine ecosystems that are particularly endangered (Bonsell \& Dunton, 2018; Constable et al., 2014; Le Guen et al., 2018; Reygondeau \& Huettmann, 2014; Rogers et al., 2020; Sen Gupta et al., 2009). As highlighted previously, changes are not equivalent across the whole Southern Ocean and can reach various degrees of importance depending on the region. Typically, it is assumed that Antarctic marine biota of the Antarctic Peninsula is today one of the most exposed regions to environmental changes (Kerr, Mata, Mendes, \& Secchi, 2018; Siegert et al., 2019). However, the general prognosis under future climate change is for an overall warming and freshening of the present-day system.

Because high latitude species are distributed at the extremity of the ocean thermal continuum and are bounded southward by the Antarctic continent, SO species will not have the 
opportunity to migrate and maintain under constant environmental conditions. In addition, Antarctic marine ecosystems are facing direct anthropogenic disturbances linked to fisheries, tourism, cruiseships and scientific activities (sewage pollution from research stations and ships, experiment pollution and lost or unrecovered equipment) (Aronson, Thatje, McClintock, \& Hughes, 2011; Lenihan \& Oliver, 1995).

In this context, Marine Protected Areas (MPAs) can constitute a relevant management tool to protect, maintain and restore biodiversity and ecosystem services. In 2005, the Commission for the Conservation of Antarctic Marine Living Resources (CCAMLR) initiated a series of proposals for creating a network of MPAs in the Southern Ocean. The South Orkney Islands southern shelf was the first MPA established in 2009, followed by the Ross Sea (Figure S1) (Brasier et al., 2018; CCAMLR, 2009). Proposals were also formulated for the Weddell Sea (Delegation of the European Union, 2018; Teschke et al., 2013), the Antarctic Peninsula (Capurro, 2017; Delegations of Argentina and Chile., 2018) and East Antarctica (Australian Antarctic Division, 2018; CCAMLR, 2013). National initiatives also led to the establishment of MPA in the sub-Antarctic area (Heard and McDonald Islands, South Georgia and South Sandwich islands, Marion and Prince Edward Islands, Magellanic Plateau and Campbell) (Atlas of marine protection, 2019; Commonwealth of Australia, 2014; Government of South Georgia and the South Sandwich Islands., 2019; Lombard et al., 2007) and France recently extended the national nature reserve of the French Southern Lands to the exclusive economic zone of Crozet and Kerguelen archipelagos (Koubbi, Causse, et al., 2016; Koubbi, Mignard, et al., 2016).

Creating and managing MPAs is essential to ensuring the representativity, persistence and connectivity between marine ecosystems (Margules \& Pressey, 2000) given that their extent, delineation, and the distance between MPAs has been adequately designed (Fernandes et al., 2005; Mora \& Sale, 2011; Roberts et al., 2003; Shanks, Grantham, \& Carr, 2003). MPAs would also limit additional anthropogenic impact on marine biodiversity. Nonetheless, a proper network of MPAs can act synergistically towards conservation goals (Grorud-Colvert et al., 2014), to protect marine biodiversity and ecosystems within/between them (McLeod, Salm, Green, \& Almany, 2009; Rees et al., 2018). This require a sufficient representation of habitat and biodiversity, including taxa with contrasted evolutionary history, patterns of dispersal, functional traits and ecological processes (Spalding, Fox, Allen, Davidson, Ferdana, et al., 2007). These aspects are essential to provide an ecological coherence assessment of an MPA network and would improve 
to the persistence and resilience of marine ecosystems and ecological processes in a context of changing world (Roberts et al., 2003, 2017).

Conservation strategies plan in the Southern Ocean mostly relies on present static ecoregionalization and biogeographic studies mainly based on current environmental predictors in the Southern Ocean. So, MPAs are commonly established based on their political and technical feasibility (Brooks, 2013) but also on this static - "snapshot" - basis that is, the current distribution of species and habitats. They do not consider the dynamics of species responses to climate change and potential distribution changes (i.e., range shift, contraction, or extension) (Araujo, Cabeza, Thuiller, Hannah, \& Williams, 2004; Hannah, 2008; Hannah et al., 2007), resulting in new biotic assemblages and species interactions that will impact ecosystem functioning (Hobbs, Valentine, Standish, \& Jackson, 2018).

In this context, the ecoregionalization approach is a promising tool to determine spatially explicit, highly cohesive, and recognizable regions characterized by common species composition and environmental settings. They are delimited from adjacent areas by distinct but dynamic boundaries and constitute operational areas to address conservation issues (Grant, 2006; Gutt et al., 2018; Koubbi et al., 2011) At the interface between biotic and environmental systems, the ecoregionalization approach can capture the interplay between species distribution and environmental changes and can predict the response of entire species assemblages to environmental changes. Ecoregions can be used to define priorities for the designation of MPAs. In the SO, ecoregions have already been delineated at regional scale for conservation purposes (Koubbi et al., 2016; Koubbi et al., 2016) based on fish assemblages (Goarant et al., 2010; Hill et al., 2017; Koubbi et al., 2011).

In the present work, we propose a temporal dynamic approach with the first benthic ecoregionalization of the entire SO which considers changes in times of environment over the next decades. The assessment of MPA network under a dynamic approach is relevant because MPA system should not only protect ecosystems and marine biodiversity in the present but also in the future. We examine the ecological representativity of benthic environments in current and proposed MPAs for the present time period [2005-2012] but also taking into account climate change scenarios [2050-2099] (RCP 4.5 and RCP 8.5) as developed by the Intergovernmental Panel on Climate Change (IPCC, 2018). Previous work studies have been conducted in this way focusing on ocean biomass evolution according to global change (Lotze et al., 2019), or on 
fisheries species (Cheung, Lam, \& Pauly, 2008; Cheung et al., 2009; Worm et al., 2009). In this study we developed a novel approach combining Ecological Niche Modeling (ENM) using Random Forest (Breiman, 1999) and model-based clustering with Gaussian Mixture Models (Fraley \& Raftery, 2006). This approach is well-suited to analyze species presence-only data, a common property of most Antarctic biodiversity datasets, and provide information on community compositions. ENM offers a baseline for detecting, monitoring and predicting the impact of climate change on species and biota (Gutt et al., 2017; Gutt et al., 2015; Kennicutt et al., 2014). An increasing number of studies have used ENM over the last decade to predict the distribution of pelagic species in the SO (Duhamel et al., 2014; Loots, Koubbi, \& Duhamel, 2007; Nachtsheim, Jerosch, Hagen, Plötz, \& Bornemann, 2017; Pinkerton et al., 2010; Thiers, Delord, Bost, Guinet, \& Weimerskirch, 2017; Xavier, Raymond, Jones, \& Griffiths, 2016) but few were developed for benthic organisms (see however: Basher \& Costello, 2016; Fabri-Ruiz, Danis, David, \& Saucède, 2018; Gallego, Dennis, Basher, Lavery, \& Sewell, 2017; Guillaumot et al., 2018; Pierrat et al., 2012).

Beyond taxonomic diversity, several studies have stressed the need to account for the different components of the biodiversity such as functional diversity in conservation plans (Lindegren, Holt, MacKenzie, \& Rahbek, 2018; Villamor \& Becerro, 2012). This is because species are not all equivalent, performing more singular functions in the ecosystem, than others (Cadotte \& Jonathan Davies, 2010; Isaac, Turvey, Collen, Waterman, \& Baillie, 2007).

For this purpose, we modeled benthic ecoregions based on the distribution of echinoid (sea urchins) fauna and a large set of environmental data. Echinoids were chosen because they constitute key species of benthic communities but are also highly rich (10\% of species worldwide) and widely distributed throughout the SO, from the shallows of the continental shelf to deep waters of abyssal plains (Arnaud et al., 1998; Barnes \& Brockington, 2003; Brandt et al., 2007; David, Choné, Mooi, \& de Ridder, 2005; Linse, Walker, \& Barnes, 2008). They belong to numerous ecological guilds (e.g., Figure S2) and are prominent and common members of benthic communities. They count epifaunal and endofaunal species that display various feeding strategies (omnivorous, deposit-feeders, carnivorous, phytophagous/algivorous, scavengers), spawning modes (broadcasting or brooding), and developmental strategies (direct developers or indirect development including a planktonic larval stage) (see, e.g., Poulin \& Féral, 1996; Saucède et al., 2014). In addition, echinoids include a large number of species (cidaroids) that provide suitable microhabitats for a varied range of sessile organisms. Cidaroids spines are colonized by relatively 
specialist sessile species and promoting an increase of sessile species richness and abundance (Hardy, David, Rigaud, De Ridder, \& Saucède, 2011; Hétérier, David, De Ridder, \& Rigaud, 2008; Linse et al., 2008). Regarding all these features, echinoid is a taxa that exhibit a high functional diversity with diversified ecological, morphological, reproductive and feeding strategies and play a major role as key species in benthic communities.

\section{Material and Methods}

1) Study area

The study area covers the entire Southern Ocean, from $45^{\circ} \mathrm{S}$ latitude to the coasts of the Antarctic continent (Figure 1) at depths ranging from the surface to $2,500 \mathrm{~m}$, a depth range for which most species occurrence data were available. The projection area includes the Antarctic continental shelf and slope, the sub-Antarctic islands and plateaus, and the continental shelf and slope of southern South America. Both existing Marine Protected Areas (MPAs) of the Southern Ocean and current CCAMLR proposals for East Antarctica, the Antarctic Peninsula and the Weddell Sea were considered to examine the representativity of ecoregions in the MPA network within the projection area (Figure S1). The geographic overlap between each ecoregion and the MPA network was computed and expressed as the proportion of each ecoregion in the overlapped MPA area (Figure 7, Table 1). To assess the quality of ecoregion representativity in the MPA network, this proportion was compared to the relative size of each ecoregion over the entire study area (Table 1).

2) Occurrence records and studied species

Species occurrence data were retrieved from an extensive and checked database of presence-only records implemented for Antarctic echinoids (Fabri-Ruiz et al. 2017). Data are available at http://ipt.biodiversity.aq/resource?r=echinoids_occurrences_southern_ocean. Species records were aggregated to a pixel size of $0.1^{\circ} \times 0.1^{\circ}$, a scale determined by the resolution of environmental data available (see below). Duplicates of species occurrence were removed from each pixel as occurrence duplication may bias model outputs (Guillaumot et al., 2019). Individual ecological niche models (ENM) were generated for each selected species before using Gaussian Mixture Models (GMM) to assemble individual models (Figure S3). Species with less than 15 pixels records after aggregation were not included in the analysis to ensure statistical robustness of 
models. Finally, 41 echinoid species were modeled, and number of cell occurrences used to build ENM are available on Figure S2. These species are distributed over the entire study area, from sub-Antarctic islands and continental shelves to the deep Antarctic slope. They are representative of the diversity of Antarctic echinoid taxa and in terms of showing various dispersal modes and feeding strategies (Figure S2).

\section{3) Environmental descriptors}

Environmental descriptors were selected on the basis of data availability and their ecological relevance for explaining the distribution of echinoids as recommended in former studies (FabriRuiz et al., 2018; Pierrat et al., 2012; Saucède et al., 2014) and more widely in species distribution modelling (Anderson, 2013; Franklin, 2010). For the present time period, environmental descriptors were extracted from the database compiled by Fabri-Ruiz et al. (2017) and averaged for the [2005-2012] period. Prior to modeling, collinearity between descriptors was evaluated using the Pairwise Pearson's correlation computed with the virtual species R package (Leroy, Meynard, Bellard, \& Courchamp, 2016). For correlation values exceeding 0.7, only one predictor of a pair was kept, that is the most relevant predictor for modeling and interpreting echinoid distribution based on ecological arguments (Fabri-Ruiz et al., 2018; Saucède et al., 2014). Finally, 13 descriptors were used to run the models; they reflect the main settings of echinoid physical habitats (depth, geomorphology, slope, sea surface temperature range, seafloor temperature range, mean seafloor temperature, sea ice cover for Antarctic species), food resources (chlorophyll a concentration) and habitat chemistry (seafloor oxygen, seafloor salinity range, mean seafloor salinity, sea surface salinity range, mean sea surface salinity) (Figure S4).

Future projections were modeled based on IPCC (International Panel on Climate Change) medium (RCP 4.5) and high (RCP8.5) carbon emission scenarios (IPCC, 2018). The predicted environmental predictors of future conditions were extracted from the NOAA database (Scott, 2019) and averaged for the [2050-2099] time period (Figure S5). Available predictors for future period are sea ice concentration, sea surface salinity, sea surface amplitude, sea surface temperature amplitude, seafloor salinity, seafloor temperature amplitude and summer chlorophyll a concentration. Seafloor oxygen was unavailable, so it remains constant across time periods.

4) Individual Species Distribution Models 
Individual Ecological Niche Models (ENM) were generated for the 41 selected species using the Random Forest algorithm (RF, Breiman, 2001) (Figure S3). This algorithm was shown appropriate and relevant for modelling Antarctic echinoid distribution in a previous work (Fabri-Ruiz et al., 2018). All models were performed using the biomod 2 package (Thuiller, Lafourcade, Engler, \& Araújo, 2009) under R.3.4 (R Core Team, 2017). The number of classification trees was set to 500 and the node size to 5 . The Mtry parameter (the number of candidate variables to include at each split) was tuned using tuneRF function from the caret package (Kuhn, 2012). Each dataset was divided in two subsets: $70 \%$ of the dataset was used a training data and the remaining $30 \%$ a test data. Occurrence records can be spatially aggregated due to the uneven sampling effort made in the different parts of the ocean to collect echinoid specimens, a bias that can alter the performance of ENM. To limit the effect of this sampling bias on model performance, the selection of pseudoabsences was weighted based on a Kernel Density Estimation (KDE) map used as a proxy of the sampling effort. The KDE map was computed with all echinoid occurrences of the database using Spatial Analyst in ArcGIS v10.2 (ESRI 2011) and following Guillaumot et al (2019). To limit the effects of the spatial autocorrelation (SAC) that breaks the «independent errors» assumption, a major issue in spatial analysis and ecological modeling (Guillaumot et al., 2019; Legendre, 1993), several replicates of pseudo-absences were generated for the model calibration. SAC of residuals was then quantified using the Moran I index computed with the ape R package (Paradis et al., 2008). Thirty replicates of pseudo-absences were selected with $p>0.5$ (with $p$, the $p$-value of the significance of Moran's I). Following Barbet-Massin and collaborators (2012), the number of simulated pseudo-absences was equal to the number of presences for each species.

The large extent of the study area implies that a wide range of environmental conditions was used to fit the models. This may lead to overestimate and extrapolate species suitable habitats (Anderson \& Raza, 2010; Barve et al., 2011; Giovanelli, de Siqueira, Haddad, \& Alexandrino, 2010). To limit extrapolation, model calibration and projection areas were delimited for each species individually within the known species depth and biogeographic range. Model predictive performance was assessed using the TSS metric (True Skill Statistic) following Allouche et al. (2006). Species projections were also converted into binary maps by maximizing the TSS method (maxTSS).

Individual species models were projected for future IPCC scenarios RCP 4.5 and RCP 8.5, including environmental conditions that may not be included in the training data, which can 
generate excessive extrapolation. To limit this effect, the multivariate environmental surface similarity (MESS) was projected on a binary map (Elith et al, 2010) using the Ecospat R package (Cola et al., 2017). The MESS maps provide a similarity index indicating the proximity of a point described by a set of environmental characteristics to the distribution of this environmental space in a population of reference points. In our case, present species binary maps were used as reference points and compared to future environmental spaces for each species individually. Areas of dissimilar environmental space (i.e., negative MESS values) were removed.

\section{5) Gaussian Mixture Model}

Individual species projections were combined to delineate benthic ecoregions using Gaussian Mixture Models (GMM) run with the mclust R package (Fraley \& Raftery, 2006). Out of the 14 geometric models available in the mclust R package (Scrucca, Fop, Murphy, \& Raftery, 2016), model VII performed best to fit the data based on the BIC (Bayesian Information Criterion) values (Figure S6). The optimal number of clusters was estimated by successively combining mixture components to minimize the entropy level (Baudry, Raftery, Celeux, Lo, \& Gottardo, 2010). Starting from a number of 20 initial clusters, clusters were gradually merged together until the entropy level reaches a minimum value (Figure S7). The same process was used with future species projections under scenarios RCP 4.5 and RCP 8.5 to predict the distribution of future ecoregions. Changes in ecoregion margins between the present period and future scenarios were quantified as the probability that future values belong to the $k^{\text {th }}$ cluster of present-day ecoregions (Figure S12 \& Figure S13). We also identified ecoregions stability in time according to the entire area but also in both MPA networks.

6) Impact of climate change on echinoid assemblages

The impact of IPCC scenarios on ecoregions was predicted by computing the percentage of changes in echinoid assemblages between present and future projections. For each pixel, the Euclidean distance between species present and future probability maps was computed based on [Eq 1] and this distance was then divided by the square root of the total species number as follows: 


$$
\% \text { of change for each pixel }=\sum_{i=1}^{n} \frac{\sqrt{\left(A_{i}-F_{i, s}\right)^{2}}}{\sqrt{N}} \times 100
$$

Where $A_{i}$ is the presence probability of species $i$ for the present period [2005-2012], $F_{i}$ the presence probability of species $i$ for the future [2050-2099], $s$ the future IPCC scenario (RCP 4.5 or RCP 8.5) and $N$ the total number of species.

To specify and quantify the direction of changes in echinoid assemblages of ecoregions, extinction and invasion rates were computed for each pixel following the approach developed by Jones and Cheung (2015). Based on species binary maps, local invasion (I) [Eq 2] and extinction rates (E) [Eq 3] were computed as follows:

$$
\begin{gathered}
I_{i, s}=\frac{n_{i, s}^{I}}{n_{i}+1} \\
E_{i, s}=\frac{n_{i, S}^{E}}{n_{i}+1}
\end{gathered}
$$

Where $n_{i}$ is the species richness for the present period [2005-2012] in cell $i, n_{i, s}^{I}$ the number of species locally invading cell $i$ under scenario $s$ (RCP 4.5 or RCP 8.5 ) and $n_{i, s}^{E}$ the number of species locally becoming extinct in cell $i$ under scenario $s$. The estimate of the local invasion rate is nonetheless a lower bound because species occurring north of $45^{\circ} \mathrm{S}$ latitude were not included in models limiting the interpretation of invasion rates to the southernmost Antarctic areas. The respective contributions of invasion and extinction rates to changes in echinoid assemblages were then tested using a Pearson correlation between the percentage of changes and invasion/extinction rates.

\section{Results}

1) Ecoregion delimitation

Twelve benthic ecoregions were identified. They are mainly partitioned into Antarctic (ecoregions $\# 1$ to \#5) and sub-Antarctic areas (ecoregions \#6 to \#12) (Figure 2). In the Antarctic, the five ecoregions are distributed in the Antarctic shelf area: on the Antarctic Inner Shelf (\#1), Antarctic Outer Shelf (\#2), and Ice shelf frontal zone (\#5), mainly located in the Weddell and the Ross seas 
as well as in the Prydz Bay area, and in deep-sea areas: on the deep shelf (\#4) and slope (\#3). In the sub-Antarctic, ecoregions are individualized as a function of depth, with: the sub-Antarctic islands and shelves (\#8) showing strong faunal and habitat affinities between Islands (northern Kerguelen Plateau, Crozet Island, Marion Prince Edward Island, and South Georgia), deep subAntarctic shelves (\#9), mainly located in southern South America, the southern part of the Kerguelen Plateau and the Campbell Plateau, and deep sub-Antarctic slopes (\#6 and \#7). Biogeographic provincialism also represents an important portion of the sub-Antarctic area with the delimitation of distinct ecoregions for the Campbell Plateau (ecoregion \#10) and the Magellanic area where two ecoregions were delineated as a function of depth: the Deep Magellanic shelf (\#11) and the Magellanic Plateau (\#12). The respective proportion of ecoregions varies between 3\% (210,892 km2 - Antarctic ecoregion \#5) and 15\% (1,078,172 km2 - subAntarctic ecoregion \#9) of the total surface area $\left(7,122,540 \mathrm{~km}^{2}\right)$ included in this study, both Antarctic and sub-Antarctic areas including small and large ecoregions. Sub-Antarctic areas however are more widely represented both in number of ecoregions (7) and surface areas (61\%).

\section{2) Environmental settings}

Mean seafloor temperature, depth and sea ice concentration are the three main abiotic factors that determine the delineation of ecoregions both between and within Antarctic and subAntarctic areas (Figures 3, S8). In all Antarctic ecoregions, sea ice concentration values are $>$ 0.5 ( $<0.5$ in sub-Antarctic ecoregions respectively) and mean seafloor temperatures $<+2{ }^{\circ} \mathrm{C}(>$ $2{ }^{\circ} \mathrm{C}$ in the sub-Antarctic respectively). The Antarctic Inner (ecoregion \#1) and Outer shelves (ecoregion \#2) differ from each other in terms of seafloor temperature, with colder temperatures in ecoregion \#1 and the Ice shelf frontal zone (ecoregion \#5) displays very low seafloor temperatures (below $0^{\circ} \mathrm{C}$ ). Within the Antarctic and sub-Antarctic areas, ecoregions are also determined according to depth. Ecoregions \#3 and \#4 show similar temperature and ice conditions but ecoregion \#3 is deeper. Deep areas $(<2,000 \mathrm{~m})$ include ecoregions \#3, \#6 and \#7. The sub-Antarctic islands and shelf areas (ecoregion \#8) are characterized by depths comprised between 0 and 1,500 $\mathrm{m}$ and a broad temperature range (between -1.8 and $+12^{\circ} \mathrm{C}$ ). Finally, the Magellanic (\#11 and \#12) and Campbell Plateau (\#10) ecoregions are characterized by the absence of sea ice and seafloor temperatures $>+4{ }^{\circ} \mathrm{C}$, ecoregion $\# 11$ being deeper and cooler than ecoregion \#12. 
3) Echinoid assemblages of ecoregions

Echinoid assemblages (Figure S9) of ecoregions include 15 species restricted to the Antarctic, 13 species restricted to the sub-Antarctic, the 13 remaining species being distributed in both provinces and in cold temperate areas. In term of species richness, Antarctic ecoregions are much richer with a total of 27 species over 7 species in the sub-Antarctic, and 9 species in the Magellanic areas and the Campbell plateau. Most Antarctic species are circum-polar in distribution and occur in the five Antarctic ecoregions, some species being widely distributed, such as Sterechinus diadema, Abatus philippii, and species of the genus Ctenocidaris found in ecoregions \#1, \#2, \#5, \#8, \#9, \#11, and \#12. High Antarctic species of ecoregion \#5 (Abatus ingens, Abatus nimrodi, Abatus shackeltoni, Abatus elongatus and Ctenocidaris rugosa) are particularly tolerant to very low seafloor temperature. In contrast, endemic species are restricted to sub-Antarctic ecoregions, such as Hygrosoma luculentum (\#10), Abatus cordatus (\#8), Arbacia dufresni (\#11 and \#12), Austrocidaris canaliculata (\#8, \#9, and \#10) and species of the genus Pseudechinus (\#8, \#9 or \#11,\#12) and Goniocidaris (\#10). These species are either deep-sea (Hygrosoma luculentum) or shallow-water species (Abatus cordatus). In contrast, sub-Antarctic ecoregion \#8 is characterized by the predominance of cold temperate (i.e. Dermechinus horridus) and widely distributed species (i.e. Ctenocidaris nutrix and Ctenocidaris speciosa). Deep-sea Antarctic and sub-Antarctic species (Sterechinus dentifer, Sterechinus diadema, Ctenocidaris speciosa, and Ctenocidaris gigantea) are widely distributed and not restricted to deep ecoregions (\#3, 4, 8, 9) only.

Interestingly, despite contrasting species richness and endemicity levels between Antarctic and sub-Antarctic ecoregions, the three main echinoid families of the Southern Ocean (Echinidae, Cidaridae, and Schizasteridae) are represented and ecologically diversified in the different ecoregions (Figures S2 \& Figure S9). Deep-sea ecoregions \#6 and \#7 show very low suitability values for all species, because the studied species are at the limit of their distribution range. However, it can be assumed that these ecoregions are suitable to deeper species that could not be included in the present analysis due to the limited number of occurrence records.

4) IPCC scenarios of climate change and ecoregions 
Predicted ecoregions according two IPCC scenarios RCP 4.5 and RCP 8.5 were projected for the [2050-2099] period (Figure 4) and the stability of ecoregion areas quantified in Figure 5. Every regions of the Southern Ocean observe instability with half of ecoregions that are expected instable in the future due to climate change (Figure 5). Under scenario RCP 4.5, the percentage of stable areas is higher than the unstable one (Figure 5b), in contrast to RCP 8.5 (Figure 5d). Instability is mainly localized in the Antarctic Peninsula, Ross Sea, Belligshausen-Amundsen seas and Campbell Plateau (Figure 5a). It extents to East Antarctica underscenario RCP 8.5 (Figure 5c) Under both IPCC scenarios, main changes should result in a southward expansion of the subAntarctic ecoregion \#8 along the Antarctic Peninsula as well as in East Antarctica under scenario RCP 8.5 (Figure 4). Future changes are also predicted to result in the loss of entire ecoregions. This is the case of the coldest Antarctic ecoregion (the Iceshelf Frontal Zone or ecoregion \#5) that could be locally replaced by the Antarctic Inner Shelf ecoregion (\#1). Ecoregion of the Campbell Plateau (Ecoregion \#10) is also predicted to be replaced by sub-Antarctic ecoregions \#8 and \#9 under both scenarios. In contrast, ecoregions of the Magellanic Plateau (\#11 and \#12) are predicted to remain stable and unchanged in the future under both scenarios.

To investigate the reason of this unstability and changes in ecoregion delineation, we projected the percentage of change in echinoids assemblages according two IPCC scenarios (Figure S10 a, b), these percentage values were also extracted for each ecoregion (Figure S10 c). Significant changes are predicted for all ecoregions of the Southern Ocean, except for deep-sea ecoregions \#6 and \#7 (Figure S10 c). The magnitude of these changes however clearly vary between ecoregions. They are predicted to be the most significant under scenario RCP 8.5 around Antarctica, over the continental shelf (ecoregions \#1, \#2 and \#5), both in East and Western Antarctica. They are particularly well marked ( $>40 \%$ ) in the Prydz Bay region and the Davis Sea under scenario RCP 8.5 only, and along the Antarctic Peninsula (ecoregion \#2) under both scenarios. In the subAntarctic ecoregions, highest changes ( $>30 \%$ ) are predicted in the southern Kerguelen Plateau, Crozet Islands and South Georgia (ecoregion \#8) under both scenarios. In contrast, few changes are predicted for the Magellanic (ecoregion \#11 and \#12) and Campbell (ecoregion \#10) plateaus, as well as for deep ecoregions (\#6 and \#7) under both scenarios $(<20 \%)$.

Changes in echinoid assemblages were expressed using invasion and extinction rates and projected for all ecoregions (Figure 6). Overall, under both scenarios, models predict higher extinction rates than invasion rates. The predicted invasions are mainly concentrated in the Ross 
Sea, the Campbell and southern Kerguelen plateaus (Figure 6a and 6b). In line with patterns of predicted changes in species assemblages (Figure S10a and S10b), local extinction rates are predicted to be the highest under scenario RCP 8.5. They mainly occur in East Antarctica and the Antarctic Peninsula as well in South Georgia, southern Kerguelen Plateau and Crozet Island (Figure 6c and 6d). In East Antarctica, extinctions are mainly predicted in the Prydz Bay area and in the Davis Sea. Along the Antarctic Peninsula, South Georgia and southern Kerguelen Plateau, extinction rates are high under both scenarios (Figure 6a, b). The Magellanic and Campbell plateaus are almost not affected by extinction.

Extinction rates are highly correlated with changes in species assemblages under both scenarios ( $r=0.73$ for RCP 4.5 and $r=0.73$ for RCP $8.5 ; p=1.531 \mathrm{e}^{-08}$ ) while correlation values are low with invasion rates $\left(r=0.02\right.$ for RCP 4.5 and $r=-0.11$ for $\left.\operatorname{RCP} 8.5 ; p=<2.2 \mathrm{e}^{-16}\right)$. This suggests that major changes in future echinoid assemblages can be expected mainly as the result of local extinctions over invasions.

5) Ecoregions and their representativity in Marine Protected Areas (MPAs)

Ecoregions are predicted to be unstable and are expected to change according to future IPCC scenarios (Figure 4 and 5). This challenges the very relevance of existing MPAs and of their current margins in the Southern Ocean as well as the representativity of present and future ecoregions in MPAs. Present sub-Antarctic ecoregions are well represented in MPAs $(>60 \%)$ compared to other ecoregions, sub-Antarctic islands (ecoregion \#8) showing the highest contributions to MPAs, followed by the sub-Antarctic deep shelf (ecoregion \#9) and deep slope areas (ecoregion \#7) (Figure 7a). In contrast, Antarctic ecoregions (ecoregions \#1 to \#5) are underrepresented in MPAs $(<15 \%)$, the Campbell Plateau (ecoregion \#10) and the Deep Magellanic shelf (ecoregion \#11) contribute to less than 10\% and ecoregions of the Magellanic Plateau are not represented in MPAs. The current proposal of CCAMLR for new MPAs in East Antarctica, Weddell Sea and Antarctic Peninsula should lead to a better representativity of Antarctic ecoregions (25\%) in MPAs, and particularly of the Antarctic Outer Shelf (ecoregion \#2).

The unbalanced representativity of ecoregions in MPAs is predicted to be strengthened in the future due to the geographic extension of sub-Antarctic ecoregions and the reduction or disappearance of Antarctic ecoregions. Under both IPCC scenarios (Figure 7b and 7c), future subAntarctic Islands (ecoregion \#8) and deep shelf areas (ecoregion \#9) should be particularly well 
represented in MPAs. In contrast, Antarctic ecoregions are predicted to be little represented, the future high Antarctic shelf (ecoregion \#5) will be the only Antarctic ecoregion to contribute to MPAs but its spatial extent is predicted to be drastically reduced (Figure 7c).

The relative proportion of stable and instable ecoregion areas in both MPA networks are relatively equivalent (about 50\%). Existing MPAs only cover 10\% of instable ecoregion areas against 13\% of stable areas (Figure 5b, d) when the proposed MPA network covers over $20 \%$ of instable and stable areas. 


\section{Discussion}

\section{1) Ecoregions}

\section{1) Species distribution patterns and the changing environment}

Antarctic ecoregions (\#1 to \#5) identified for the present period show a high species richness compared to other ecoregions (Figure S9). In total, Antarctic echinoid species distributed south of the Polar Front account for about 10\% of all known echinoid species reported worldwide (Saucède et al., 2014), making Antarctic regions higher than expected enriched in terms of echinoid diversity. The species richness of the Antarctic continental shelf was already demonstrated in previous works for echinoids, with the highest values found between $100 \mathrm{~m}$ and $1000 \mathrm{~m}$ depth along the Antarctic Peninsula, eastern Weddell sea and East Antarctica (Saucède et al., 2014); a similar pattern was also found in other marine groups (Chenuil et al., 2018; Clarke, 2008; Lecointre et al., 2013; Saucède et al., 2014). The speciose families Cidaridae and Schizasteridae in the Antarctic (Poulin \& Féral, 1996), which represent about 65\% of all Antarctic echinoid species, are also highly endemic to the Antarctic continental shelf with $81 \%$ and $67 \%$ of endemic species respectively (David et al., 2005; Pearse, Mooi, Lockhart, \& Brandt, 2009; Pierrat et al., 2012; Saucède et al., 2014). This high level of endemicity and the prevalence of a taxonomically limited number of speciose groups was found in many other marine groups in the Antarctic, and particularly on the continental shelf where species flocks were identified (Chenuil et al., 2018; Clarke \& Crame, 2010; Eastman, 2000; Lecointre et al., 2013). Endemicity is even more pronounced in the less-extended sub-Antarctic ecoregions (Hygrosoma luculentum (\#10), Abatus cordatus (\#8), Arbacia dufresni (\#11 and \#12), Austrocidaris canaliculata (\#8,\#9, and \#10) and species of the genus Pseudechinus (\#8, \#9 or \#11, \#12) and Goniocidaris (\#10)) as already highlighted in previous studies (David et al., 2005; Fabri-Ruiz et al., 2018; Guillaumot et al., 2018; Saucède et al., 2014). Species endemicity and adaptation to cold and subzero water temperatures make these organisms particularly vulnerable to climate warming, especially along the Antarctic Peninsula and in the sub-Antarctic islands, which are subject to fast warming and are impacted by the synergetic effects of multiple stressors such as changes in sea ice regimes and seasonality, ice-shelf collapse and iceberg scouring, reduced salinity and increased in UV-B radiation (Fabri-Ruiz et al., 2018; Guillaumot et al., 2018; Gutt et al., 2015; Meredith \& King, 2005; Turner et al., 2014). 
Depth, sea ice concentration and seafloor temperature are the three environmental factors that most contribute to the definition of ecoregions (Figure 3) which is in line with previous findings obtained for Antarctic echinoids (Fabri-Ruiz et al., 2018; Pierrat et al., 2012). The importance of depth as a driver of species distribution has long been substantiated for echinoids (Brey \& Gutt, 1991; David et al., 2005; Fabri-Ruiz et al., 2018; Jacob, Terpstra, \& Brey, 2003; Pierrat et al., 2012; Reiss, Cunze, König, Neumann, \& Kröncke, 2011) and for other marine groups (Gogina, Glockzin, \& Zettler, 2010; Pierrat et al., 2012; Reiss et al., 2011). Depth is not expected to change in a near future at large spatial scale (i.e., the scale of the present analysis) but the effects of sea level rise are expected to affect intertidal and subtidal communities at local scale in polar regions (Kaiser, Barnes, \& Brandt, 2007). In contrast, important changes are predicted in sea ice cover and seafloor temperatures (IPCC, 2018). They both are important drivers of Southern Ocean communities (Peck, 2005; Waller, Worland, Convey, \& Barnes, 2006) that determine the abundance, richness, and diversity of species assemblages (Moya, Saucede, \& Manjón-Cabeza, 2012). Sea ice cover also acts as a protection for benthic organisms by reducing potential UV-Binduced damage on organisms, particularly for those with planktonic larval stages (Gutt et al., 2015; Lister, Lamare, \& Burritt, 2010). The reduction in sea ice concentration, extent, and seasonality, along with seafloor temperature increase will drive significant changes in species assemblages and in the identification of future ecoregions (Figures 4, S9).

\section{2) Biogeographic provinces and regionalizations of the Southern Ocean}

In the present work, we propose the first dynamic benthic ecoregionalization of the entire Southern Ocean based on species distribution models of a large set of benthic species albeit belonging to one single taxonomic class. However, the biogeographic relevance and representativity of these ecoregions is supported for the entire benthos by the relatively good match with common biogeographic patterns described in former studies. Specifically, this holds true for echinoids (Pierrat, Saucède, Brayard, \& David, 2013) but also for other marine invertebrates like sponges (Downey, Griffiths, Linse, \& Janussen, 2012), mollusks (Linse, Griffiths, Barnes, \& Clarke, 2006; Pierrat et al., 2013), bryozoans (Barnes \& Griffiths, 2007; Griffiths et al., 2009), and starfish (Moreau et al., 2017). The distinction between Antarctic and sub-Antarctic regions (Barnes \& Griffiths, 2007; Downey et al., 2012; Griffiths et al., 2009; Linse et al., 2006; Pierrat et al., 2013), faunal affinities between the Scotia Arc region and South 
America (ecoregion \#8 and \#9) (Clarke, Barnes, \& Hodgson, 2005; Fraser, Kay, Plessis, \& Ryan, 2017; Fraser et al., 2018) and the similarities between sub-Antarctic islands (Kerguelen, Crozet, Marion Prince Edward), South America and South Georgia (ecoregion \#8) were emphasized in previous biogeographic works on echinoids, bivalves (Pierrat et al., 2013), cheilostome bryozoans (Griffiths et al., 2009) and starfish (Moreau et al., 2017). This is related to the effect of the Antarctic Circumpolar Current, which acts as a dispersal vector for benthic organisms (GonzálezWevar et al., 2018; Moon, Chown, \& Fraser, 2017; Pearse et al., 2009). The Campbell Plateau and the Ross Sea (ecoregions \#8 and \#9) also have faunal affinities, which have already been reported for echinoids (Pierrat et al., 2013), bivalves, gastropods (Pierrat et al., 2013) and starfish (Moreau et al., 2017).

The congruence between present ecoregions and general biogeographic patterns of of the SO benthos organisms can be explained firstly by the contribution of abiotic factors. Typically, depth, seafloor temperature and sea ice concentration are important contributors to ecoregions delineation; they are also important drivers of the benthos distribution at large spatial scale (David et al., 2005; Guillaumot et al., 2019; Gutt, 2001; Pierrat et al., 2012). General biogeographic patterns are also the legacy of common evolutionary events triggered by climate history and the paleogeography of the SO (Crame, 2018; Saucède, Pierrat, Brayard, \& David, 2013; Saucède et al., 2014). Finally, echinoid fauna shows a high functional diversity (Figure S1) that is representative of most benthic communities, suspension feeders excepted. Species echinoids are characterized by slow metabolism and growth rates (Peck, 2018), high longevity (Brey, Pearse, Basch, McClintock, \& Slattery, 1995; Brey, 1991), different reproduction strategies (broadcasters versus brooders) (Figure S2) but they also belong to different ecological guilds and trophic levels (Figure S2).

Over the last 20 years, technical advances promoted the exploration of the deep sea and the development of marine remote observing systems (satellites) along with big data analysis tools (Briggs \& Bowen, 2012; Costello et al., 2017; Longhurst, 2007; Reygondeau et al., 2013; Spalding et al., 2007) facilitated the assessment of biotic regions of the Southern Ocean (De Broyer \& Koubbi, 2014). For instance, the SO has been partitioned into biogeochemical provinces based on satellite data (Longhurst, 2007) proposing to divide the Southern Ocean into a south subtropical, a sub-Antarctic, Antarctic and Austral polar provinces. Raymond (2014) proposed to divide the SO into 20 regions based on abiotic environmental data, a regionalization approach refined by Douglass and co-authors (2014) using benthic abiotic and biotic data. This last 
regionalization of the Southern Ocean was focused on the CCAMLR convention area, thus excluding South America and New Zealand (Douglass et al., 2014). With the exception of the deep sea, most of these formerly defined regions present a relatively good match with our ecoregions. For instance, Raymond's regions \#13 and \#14 correspond to ecoregions \#8 and \#9 in the northern and southern part of the Kerguelen Plateau.

\section{The impact of predicted environmental changes}

Part of the Southern Ocean is facing some of the fastest environmental changes (Convey et al., 2009; Gutt et al., 2015; Turner et al., 2014; Turner \& Comiso, 2017) and numerous studies have highlighted the vulnerability of high latitude species to climate change. Possible species responses can be the migration to deeper and colder areas, the southward migration of sub-Antarctic species, the resilience and maintenance of current distributions, or local to regional extinctions (Barnes \& Peck, 2008; Constable et al., 2014; Griffiths, Meijers, \& Bracegirdle, 2017; Peck, 2005). Our approach uses for the first time a dynamic ecoregionalization approach to understand the impact of environmental change on ecoregions delineation at the scale of the Southern Ocean. The present results suggest a high spatial instability in the modeled ecoregions with important changes predicted along the Antarctic Peninsula and the Amundsen and Bellingshausen seas (Ecoregion

\#2) under both IPCC scenarios, as well as the prevalence of local extinctions over maintenance and invasions (Figures 4, 5,6, S10).

The Antarctic Peninsula and the Amundsen and Bellingshausen seas have already been identified as the most impacted regions of the SO by climate change (Bracegirdle, Connolley, \& Turner, 2008; Turner et al., 2014, 2009). Our results also suggest that other regions in East Antarctica, particularly in Prydz Bay and Davis Sea, and in the Ross Sea to a lesser extent, might also be strongly impacted under scenario RCP 8.5. Temperature increase, changes in sea ice seasonality and sea ice extent are predicted to strongly contribute to such changes in the Antarctic (Ingels et al., 2012; Lohrer et al., 2013). Variations in these environmental parameters could affect the onset and the magnitude of phytoplankton blooms, conditioning the export of the organic matter export to the seafloor, which is an essential nutrient for benthic communities (Jansen et al., 2018; Smith \& Sandwell, 1997) and for echinoids in particular. Many echinoid species, such as in the Schizasteridae family, feed on the organic matter associated to sediments (De Ridder, 1982; Michel, David, Dubois, Lepoint, \& De Ridder, 2016). Omnivorous species such as Sterechinus 
neumayeri and Sterechinus diadema are also partly dependent on this food intake through benthopelagic coupling (Jacob et al., 2003; Michel et al., 2016). Decrease in sea ice concentration is also expected to unveil new habitats but also affect benthic colonization and succession processes (Barnes \& Conlan, 2007).

In the sub-Antarctic regions, the predicted changes in echinoid assemblages in South America, on the Campbell and Kerguelen plateaus are consistent with recent studies (Griffiths et al., 2017; Guillaumot et al., 2018). High extinction rates predicted for the Crozet islands, Kerguelen Plateau and South Georgia could be related to a southward migration of the Antarctic Circumpolar Current, and particularly of the sub-Antarctic and Polar fronts (Allan et al., 2013).

Extinction and invasion rates will result in changes in the composition of echinoid assemblages and consequently, to the delineation of ecoregions that are predicted to shift. The Iceshelf Frontal Zone is predicted to disappears from the Ross Sea, which would become suitable for other Antarctic species from ecoregions \#1 and \#2. Our results show that Antarctic ecoregions $\# 1$ and \#2 could persist in the future in the Ross and Weddell seas under both scenarios and in East Antarctic under scenario RCP 4.5 scenarios. Most importantly, they could constitute potential refugia and conservation areas for Antarctic species in the future. Under both scenarios, ecoregion \#8 is predicted to shift southward in the Antarctic area that would turn suitable for sub-Antarctic species but not for Antarctic species anymore. Disappearance of ecoregion \#10 on the Campbell Plateau also highlights the vulnerability of endemic species such as Hygrosoma luculentum

\section{Marine Protected Areas}

In the Southern Ocean, the establishment of MPAs is based on either national policies or international cooperation under the umbrella of CCAMLR. National entities do not necessarily act synergistically or co-operatively but MPAs can be a useful tool to manage the impact of fisheries and of other human activities (e.g., cruiseships and tourism) on marine ecosystems, and enhance the resilience of ecosystems to climate change (Carr et al., 2017; Fredston-Hermann, Gaines, \& Halpern, 2018; Hannah, 2008; Roberts et al., 2003). MPAs representativity of species and habitat diversity, including endemic and rare species (Agardy, 2000; Caldecott, Jenkins, Johnson, \& Groombridge, 1996; Lawler, White, Sifneos, \& Master, 2003) is required by international agreements, such as the Convention on Biological Diversity (CBD, 1992), and is a major concern conditioning the relaunch of MPAs (Chauvenet, Kuempel, McGowan, Beger, \& Possingham, 2017; Fischer, Bhakta, Macmillan-Lawler, \& Harris, 2019). Moreover, the strategic plan for 
biological diversity was adopted and fixed at the horizon H2020 during the conference of the parties (COP 10) in Nagoya in 2010 to improve the state of biological diversity but also to lessen anthropogenic pressures on it (Buck \& Hamilton, 2011).

In the present work, 12 ecoregions were identified for the SO. The network of current MPAs shows a good representativity of current sub-Antarctic ecoregions and of sub-Antarctic islands in particular (ecoregion \#8 - Table 1). Ecoregion \#8 covers multiple islands and isolated shelves including the South Georgia, Crozet Islands, the Kerguelen Plateau and the Campbell Plateau. These areas are of high conservation value given the extreme isolation of small oceanic islands and archipelagoes where unique habitats and endemic species may be particularly at risk. This is exemplified by the echinoid Abatus cordatus and its emblematic populations that thrive in shallow coastal areas of the Kerguelen Islands (Guillaumot et al., 2018; Saucède et al., 2017).

The MPA network preserves faunal connectivity between populations and species of the sub-Antarctic islands and shelves. Connectivity is key in conservation biology as it determines conditions the resilience of populations under critical conditions or after local disturbances (Carr et al., 2017). As opposed to ecoregion $\# 8$, ecoregions $\# 10$ and $\# 11$ are reduced to restricted portions of the Southern Ocean that also include endemic species (the Campbell and Magellanic plateaus respectively). These spatially-restricted ecoregions are well represented in the present MPAs as well.

In contrast, important gaps prevail in the network of existing MPAs as Antarctic ecoregions are under-represented $(20 \%)$ and models even predict a weaker representativity in the future $(10 \%)$ under both IPCC scenarios. A consistent MPA networks is essential to reduced stress areas and promote resilient biological communities with a greater capacity to recover after environmental crises (Bates et al., 2019; Roberts et al., 2017). It improves the connectivity between areas but also promote genetic diversity that provides key material for adaptation to climate change (Roberts et al., 2017). In addition, MPAs in which stressors are kept under control (e.g., fisheries activity) can constitute real sentinels (research) sites to improve our knowledge of climate change and track its effects on marine biodiversity (Agardy, 1994).

Results of the present study stress the need to improve representativity of the present network of MPAs in the Antarctic area as recently proposed by CCAMLR for East Antarctica, the Weddell Sea and the Antarctic Peninsula (Australian Antarctic Division, 2018; Delegation of the European Union, 2018; Delegations of Argentina and Chile., 2018). East Antarctica (Drygalsky, d'Urville- Sea Mertz, MacRobertson) remains unprotected whereas a first plan was proposed to 
CCAMLR in 2012 by the European Union and Australia. Tourism is increasing (Aronson et al., 2011; Lenihan \& Oliver, 1995) in Antarctica along the Antarctic Peninsula and the Weddell Sea due to the proximity of these regions with South America. New MPA proposals were also made for these two regions in 2013 and 2017 (Capurro, 2017; Teschke et al., 2013). The present and future models therefore support the relevance of the proposed Antarctic MPAs, which should improve the ecological representativity of Antarctic ecoregions (ecoregions \#1 to \#5). Current and proposed MPAs also fail to include the Magellanic plateau ecoregion (\#12). However, this region belongs to the exclusive economic zones of Argentina and United Kingdom that could trigger national conservation plans.

Our results predict a southward extension of future sub-Antarctic ecoregions and conversely, a reduction of Antarctic ecoregions that would become even more under-represented in MPAs in the future (Figure 4). Climate change is also predicted to lead to the disappearance of ecoregion \#10. These results highlight the need for a dynamic designation for MPAs in response to a changing environment. Despite instability in ecoregions and high predicted extinction rates in Antarctica, ten ecoregions and stable areas are still identified and represented under future scenarios and could constitute possible refugia for the Antarctic benthic fauna, especially in the proposed MPAs network. Moreover, as discussed above, the Antarctic Peninsula and the Weddell Sea are targeting areas for tourism and cruise ships and new MPA proposals should favor a strict management of these activities in areas highly impacted by climate change. In view of our results, CCAMLR MPA proposals should be set up for a better representativity of current ecoregions.

Beyond the considered Southern Ocean MPAs networks, the representativity of ecoregions is certainly biased in our knowledge of species distribution. Well-represented ecoregions in both MPAs networks often correspond to areas that have actively been sampled and studied (Griffiths, Van de Putte, \& Danis, 2014). This is the case of ecoregion \#8, which is well represented in MPAs and relatively well-sampled, the Kerguelen Plateau in particular. In contrast, ecoregions \#1 and \#2 cover poorly known areas such as East Antarctica or the Amundsen-Bellingshausen seas. The same holds true for deep ecoregions (\#3, \#4 and \#7).

Proxies such as temperature, depth, salinity, oxygen concentration, light availability and sediment composition, current velocity are often used as surrogates of biodiversity assessments for conservation planning of little sampled and poorly known areas (Dalleau et al., 2010; Hogg, Huvenne, Griffiths, \& Linse, 2018; McArthur et al., 2010; Rees, Jordan, Price, Coleman, \& Davis, 2014). There are however important drawbacks to this approach, mainly to generate a (1) false 
homogeneity, where sites with similar abiotic conditions exhibit different biological compositions or conversely, a (2) false heterogeneity, where sites with different abiotic conditions support very similar biological distributions (Williams et al., 2018).

Considering these biases and the threats to the Southern Ocean, the representation of ecoregions can be improved beyond current CCAMLR MPA proposals. We do think that replicate protection across different ocean basins are relevant and should not only focus on the West Antarctic where the sampling effort is strong. Our results underline the importance of East Antarctica, little covered by scientific survey, highly fragmented and with a strong potential contribution to Antarctic ecoregions. Additional MPAs such as think in the first conservation plan initiated in 2012, which included three supplementary MPAs (Gunnerus, Enderby and Wilkes) to those existing (Brooks et al., 2016; Wenzel et al., 2016), would increase ecoregions representation and improve their connectivity. Regions such as Prydz, which is sensitive to local extinction and ecoregions instability under RCP 8.5 could there included in as potential conservation area.

The present work is based on the distribution modeling of a class of benthic invertebrates that presents a high species diversity. Nevertheless, our results underline that these ecoregions are consistent with main biogeographic patterns described in other bentic taxa of the Consequently, it provides useful quantitative indicators of the current structure of a SO benthic fauna and its potential response to climate change under IPCC scenarios.

This should therefore encourage conservation managers and scientists to strengthen their efforts to use a dynamical ecoregionalization approach as a decision-making tool to address conservation issues in the framework of existing MPAs but also to identify potential conservation areas. Extending this approach to other taxa and ecological guilds should improve our understanding of the current, transient dynamics of marine life in the Southern Ocean and how environmental changes will impact its spatial structure and dynamics in the future.

\section{Acknowledgments}

This research was supported by the French Polar Institute - IPEV (program n ${ }^{\circ} 1044$ - Proteker). It is respectively contribution $\mathrm{n}^{\circ} 36$ and $\mathrm{n}^{\circ} 9$ to the vERSO and RECTO projects (http://www.rectoversoprojects.be ), funded by the Belgian Science Policy Office (BELSPO). 


\section{Data Sharing and Accessibility}

All occurrences species data used for this study are open-access and available here: http://ipt.biodiversity.aq/resource?r=echinoids_occurrences_southern_ocean

All environmental layers are also open-access and available here: https://data.aad.gov.au/metadata/records/Environmental_data_Southern_Ocean

\section{References}

Agardy, T. (1994). Advances in marine conservation: the role of marine protected areas. Trends in Ecology \& Evolution, 9(7), 267-270.

Agardy, T. (2000). Information needs for marine protected areas: scientific and societal. Bulletin of Marine Science, 66(3), 875-888.

Allan, E., William Froneman, P., Durgadoo, J. V., McQuaid, C. D., Ansorge, I. J., \& Richoux, N. B. (2013). Critical indirect effects of climate change on sub-Antarctic ecosystem functioning. Ecology and Evolution, 3(9), 2994-3004. https://doi.org/10.1002/ece3.678

Allouche, O., Tsoar, A., \& Kadmon, R. (2006). Assessing the accuracy of species distribution models: prevalence, kappa and the true skill statistic (TSS): Assessing the accuracy of distribution models. Journal of Applied Ecology, 43(6), 1223-1232. https://doi.org/10.1111/j.13652664.2006.01214.x

Anderson, R. P. (2013). A framework for using niche models to estimate impacts of climate change on species distributions. Annals of the New York Academy of Sciences, 1297(1), 8-28.

Anderson, R. P., \& Raza, A. (2010). The effect of the extent of the study region on GIS models of species geographic distributions and estimates of niche evolution: preliminary tests with montane rodents (genus Nephelomys) in Venezuela. Journal of Biogeography, 37(7), 1378-1393. https://doi.org/10.1111/j.1365-2699.2010.02290.x 
Araujo, M. B., Cabeza, M., Thuiller, W., Hannah, L., \& Williams, P. H. (2004). Would climate change drive species out of reserves? An assessment of existing reserve-selection methods. Global Change Biology, 10(9), 1618-1626. https://doi.org/10.1111/j.1365-2486.2004.00828.x

Arnaud, P. M., López, C. M., Olaso, I., Ramil, F., Ramos-Esplá, A. A., \& Ramos, A. (1998). Semi-quantitative study of macrobenthic fauna in the region of the South Shetland Islands and the Antarctic Peninsula. Polar Biology, 19(3), 160-166.

Aronson, R. B., Thatje, S., McClintock, J. B., \& Hughes, K. A. (2011). Anthropogenic impacts on marine ecosystems in Antarctica. Annals of the New York Academy of Sciences, 1223(1), 82-107.

Atlas of marine protection. (2019, October 28). Cabo de Hornos UNESCO-MAB Biosphere Reserve (Reserva Biósfera). Retrieved from http://www.mpatlas.org/mpa

Australian Antarctic Division. (2018). A Marine Protected Area for East Antarctica: Australian Government. Department of the Environment and Energy. Retrieved from http://www.antarctica.gov.au/law-and-treaty/ccamlr/marine-protected-areas.

Barbet-Massin, M., Jiguet, F., Albert, C. H., \& Thuiller, W. (2012). Selecting pseudo-absences for species distribution models: how, where and how many?: How to use pseudo-absences in niche modelling? Methods in Ecology and Evolution, 3(2), 327-338. https://doi.org/10.1111/j.2041210X.2011.00172.X

Barnes, D. K. A., \& Brockington, S. (2003). Zoobenthic biodiversity, biomass and abundance at Adelaide Island, Antarctica. Marine Ecology Progress Series, 249, 145-155. https://doi.org/10.3354/meps249145

Barnes, D. K. A., \& Conlan, K. E. (2007). Disturbance, colonization and development of Antarctic benthic communities. Philosophical Transactions of the Royal Society B: Biological Sciences, 362(1477), 11-38. https://doi.org/10.1098/rstb.2006.1951

Barnes, D. K. A., \& Griffiths, H. J. (2007). Biodiversity and biogeography of southern temperate and polar bryozoans. Global Ecology and Biogeography, 17, 84-99. https://doi.org/10.1111/j.1466-8238.2007.00342.x

Barnes, D. K. A., \& Peck, L. (2008). Vulnerability of Antarctic shelf biodiversity to predicted regional warming. Climate Research, 37(2-3), 149-163. https://doi.org/10.3354/cr00760

Barve, N., Barve, V., Jiménez-Valverde, A., Lira-Noriega, A., Maher, S. P., Peterson, A. T., ... 
Villalobos, F. (2011). The crucial role of the accessible area in ecological niche modeling and species distribution modeling. Ecological Modelling, 222(11), 1810-1819. https://doi.org/10.1016/j.ecolmodel.2011.02.011

Basher, Z., \& Costello, M. J. (2016). The past, present and future distribution of a deep-sea shrimp in the Southern Ocean. PeerJ, 4, e1713. https://doi.org/10.7717/peerj.1713

Bates, A. E., Cooke, R. S., Duncan, M. I., Edgar, G. J., Bruno, J. F., Benedetti-Cecchi, L., ... Barrett, N. (2019). Climate resilience in marine protected areas and the 'Protection Paradox.' Biological Conservation, 236, 305-314.

Baudry, J.-P., Raftery, A. E., Celeux, G., Lo, K., \& Gottardo, R. (2010). Combining Mixture Components for Clustering. Journal of Computational and Graphical Statistics, 19(2), 332-353. https://doi.org/10.1198/jcgs.2010.08111

Bonsell, C., \& Dunton, K. H. (2018). Long-term patterns of benthic irradiance and kelp production in the central Beaufort sea reveal implications of warming for Arctic inner shelves. Progress in Oceanography, 162, 160-170. https://doi.org/10.1016/j.pocean.2018.02.016

Bracegirdle, T. J., Connolley, W. M., \& Turner, J. (2008). Antarctic climate change over the twenty first century. Journal of Geophysical Research, 113(D3), 1-13. https://doi.org/10.1029/2007JD008933

Bracegirdle, T. J., Shuckburgh, E., Sallee, J.-B., Wang, Z., Meijers, A. J. S., Bruneau, N., ... Wilcox, L. J. (2013). Assessment of surface winds over the Atlantic, Indian, and Pacific Ocean sectors of the Southern Ocean in CMIP5 models: historical bias, forcing response, and state dependence: CMIP5 Southern Ocean surface winds. Journal of Geophysical Research: Atmospheres, 118(2), 547-562. https://doi.org/10.1002/jgrd.50153

Brandt, A., Gooday, A. J., Brandão, S. N., Brix, S., Brökeland, W., Cedhagen, T., ... Vanreusel, A. (2007). First insights into the biodiversity and biogeography of the Southern Ocean deep sea. Nature, 447(7142), 307-311. https://doi.org/10.1038/nature05827

Brasier, M. J., Grant, S. M., Trathan, P. N., Allcock, L., Ashford, O., Blagbrough, H., ... Eléaume, M. P. (2018). Benthic biodiversity in the South Orkney Islands Southern shelf marine protected area. Biodiversity, 19(1-2), 5-19.

Breiman, L. (1999). Random forests. UC Berkeley TR567. Retrieved from 
http://machinelearning202.pbworks.com/w/file/fetch/60606349/breiman_randomforests.pdf

Brey, T., Pearse, J., Basch, L., McClintock, J., \& Slattery, M. (1995). Growth and production of Sterechinus neumayeri (Echinoidea: Echinodermata) in McMurdo Sound, Antarctica. Marine Biology, 124(2), 279-292. https://doi.org/10.1007/BF00347132

Brey, T. (1991). Population dynamics of Sterechinus antarcticus (Echinodermata: Echinoidea) on the Weddell Sea shelf and slope, Antarctica. Antarctic Science, 3(3), 251-256.

Brey, T., \& Gutt, J. (1991). The genus Sterechinus (Echinodermata: Echinoidea) on the Weddell Sea shelf and slope (Antarctica): distribution, abundance and biomass. Polar Biology, 11(4), 227232.

Briggs, J. C., \& Bowen, B. W. (2012). A realignment of marine biogeographic provinces with particular reference to fish distributions: Marine biogeographic provinces. Journal of Biogeography, 39(1), 12-30. https://doi.org/10.1111/j.1365-2699.2011.02613.x

Brooks, C. M. (2013). Competing values on the Antarctic high seas: CCAMLR and the challenge of marine-protected areas. The Polar Journal, 3(2), 277-300.

Brooks, C. M., Crowder, L. B., Curran, L. M., Dunbar, R. B., Ainley, D. G., Dodds, K. J., ... Sumaila, U. R. (2016). Science-based management in decline in the Southern Ocean. Science, 354(6309), 185-187.

Buck, M., \& Hamilton, C. (2011). The Nagoya Protocol on Access to Genetic Resources and the Fair and Equitable Sharing of Benefits Arising from their Utilization to the Convention on Biological Diversity. Review of European Community \& International Environmental Law, 20(1), 47-61. https://doi.org/10.1111/j.1467-9388.2011.00703.x

Cadotte, M. W., \& Jonathan Davies, T. (2010). Rarest of the rare: advances in combining evolutionary distinctiveness and scarcity to inform conservation at biogeographical scales. Diversity and Distributions, 16(3), 376-385.

Caldecott, J. O., Jenkins, M. D., Johnson, T. H., \& Groombridge, B. (1996). Priorities for conserving global species richness and endemism. Biodiversity and Conservation, 5(6), 699-727. https://doi.org/10.1007/BF00051782

Capurro, A. (2017). Domain 1 Marine Protected Area Preliminary Proposal PART A-1: Priority Areas for Conservation. SC-CAMLR-XXXVI/17. 
Carr, M. H., Robinson, S. P., Wahle, C., Davis, G., Kroll, S., Murray, S., ... Williams, M. (2017).

The central importance of ecological spatial connectivity to effective coastal marine protected areas and to meeting the challenges of climate change in the marine environment. Aquatic Conservation: Marine and Freshwater Ecosystems, 27(S1), 6-29. https://doi.org/10.1002/aqc. 2800

CBD. (1992). Convention on biological diversity. Convention on Biological Diversity.

CCAMLR. Conservation Measure 91-03. Protection of the South Orkney Islands southern shelf. Hobart, Tasmania, Australia. , (2009).

CCAMLR. (2013). Proposal for a conservation measure establishing an East Antarctic Representative System of Marine Protected Areas. Paper submitted by Australia, France and the European Union. CCAMLR-XXXII/34 Rev 1. CCAMLR-XXXII/34.

Chauvenet, A. L. M., Kuempel, C. D., McGowan, J., Beger, M., \& Possingham, H. P. (2017). Methods for calculating Protection Equality for conservation planning. PLOS ONE, 12(2), e0171591. https://doi.org/10.1371/journal.pone.0171591

Cheng, C. H., \& William, H. W. (2007). Molecular ecophysiology of Antarctic notothenioid fishes. Philosophical Transactions of the Royal Society B: Biological Sciences, 362(1488), 22152232. https://doi.org/10.1098/rstb.2006.1946

Chenuil, A., Saucède, T., Hemery, L. G., Eléaume, M., Féral, J.-P., Améziane, N., ... Havermans, C. (2018). Understanding processes at the origin of species flocks with a focus on the marine A ntarctic fauna. Biological Reviews, 93(1), 481-504.

Cheung, W. W. L., Lam, V. W. Y., \& Pauly, D. (2008). Modelling present and climate-shifted distribution of marine fishes and invertebrates. https://doi.org/10.14288/1.0074754

Cheung, W. W. L., Lam, V. W. Y., Sarmiento, J. L., Kearney, K., Watson, R., \& Pauly, D. (2009). Projecting global marine biodiversity impacts under climate change scenarios. Fish and Fisheries, 10(3), 235-251. https://doi.org/10.1111/j.1467-2979.2008.00315.x

Clarke, A. (2008). Antarctic marine benthic diversity: patterns and processes. Journal of Experimental Marine Biology and Ecology, 366(1-2), 48-55.

Clarke, A., Barnes, D. K. A., \& Hodgson, D. A. (2005). How isolated is Antarctica? Trends in Ecology \& Evolution, 20(1), 1-3. 
Clarke, A., \& Crame, J. A. (2010). Evolutionary dynamics at high latitudes: speciation and extinction in polar marine faunas. Philosophical Transactions of the Royal Society B: Biological Sciences, 365(1558), 3655-3666.

Cola, V. D., Broennimann, O., Petitpierre, B., Breiner, F. T., D’Amen, M., Randin, C., ... Guisan, A. (2017). ecospat: an R package to support spatial analyses and modeling of species niches and distributions. Ecography, 40(6), 774-787. https://doi.org/10.1111/ecog.02671

Commonwealth of Australia. (2014). Heard Island and McDonald Islands Marine Reserve Management Plan 2014-2024. 99.

Constable, A. J., Melbourne-Thomas, J., Corney, S. P., Arrigo, K. R., Barbraud, C., Barnes, D. K. A., ... Ziegler, P. (2014). Climate change and Southern Ocean ecosystems I: how changes in physical habitats directly affect marine biota. Global Change Biology, 20(10), 3004-3025. https://doi.org/10.1111/gcb.12623

Convey, P., Bindschadler, R., Di Prisco, G., Fahrbach, E., Gutt, J., Hodgson, D. A., ... Consortium, A. (2009). Antarctic climate change and the environment. Antarctic Science, 21(6), $541-563$.

Costello, M. J., Tsai, P., Wong, P. S., Cheung, A. K. L., Basher, Z., \& Chaudhary, C. (2017). Marine biogeographic realms and species endemicity. Nature Communications, 8(1), 1057. https://doi.org/10.1038/s41467-017-01121-2

Crame, J. A. (2018). Key stages in the evolution of the Antarctic marine fauna. Journal of Biogeography, 45(5), 986-994.

Dalleau, M., Andréfouët, S., Wabnitz, C. C. C., Payri, C., Wantiez, L., Pichon, M., ... Benzoni, F. (2010). Use of Habitats as Surrogates of Biodiversity for Efficient Coral Reef Conservation Planning in Pacific Ocean Islands. Conservation Biology, 24(2), 541-552. https://doi.org/10.1111/j.1523-1739.2009.01394.x

David, B., Choné, T., Mooi, R., \& de Ridder, C. (2005). Antarctic echinoidea (Vol. 10). Liechtenstein: ARG Gantner.

David, B., \& Mooi, R. (1990). An echinoid that "gives birth": morphology and systematics of a new Antarctic species, Urechinus mortenseni (Echinodermata, Holasteroida). Zoomorphology, $110(2), 75-89$. 
De Broyer, C., \& Koubbi, P. (2014). The biogeography of the Southern Ocean. In C. De Broyer, P. Koubbi, H. J. Griffiths, B. Raymond, C. d'Udekem d'Acoz, A. P. Van de Putte, ... Y. RopertCoudert (Eds.), Biogeographic Atlas of the Southern Ocean (pp. 418-421). Cambridge UK: Scientific Committee on Antarctic Research.

De Ridder, C. (1982). Food and feeding mechanisms: Echinoidea. Echinoderm Nutrition, 57-115.

Delegation of the European Union. EU proposal to establish the Weddell Sea MPA (WSMPA). CCAMLR-XXXVII/29. , (2018).

Delegations of Argentina and Chile. Proposal on a conservation measure establishing a marine protected area in the Domain 1 (Western Antarctic Peninsula and South Scotia Arc). CCAMLRXXXVII/31., (2018).

Douglass, L. L., Turner, J., Grantham, H. S., Kaiser, S., Constable, A., Nicoll, R., ... Beaver, D. (2014). A Hierarchical Classification of Benthic Biodiversity and Assessment of Protected Areas in the Southern Ocean. PLoS ONE, 9(7), e100551. https://doi.org/10.1371/journal.pone.0100551

Downey, R. V., Griffiths, H. J., Linse, K., \& Janussen, D. (2012). Diversity and Distribution Patterns in High Southern Latitude Sponges. PLoS ONE, 7(7), e41672. https://doi.org/10.1371/journal.pone.0041672

Duhamel, G., Hulley, P.-A., Causse, R., Koubbi, P., Vacchi, M., Pruvost, P., ... Belchier, M. (2014). Biogeographic patterns of fish. In Biogeographic atlas of the Southern Ocean. Cambridge, SCAR: Scientific Committee on Antarctic Research.

Eastman, J. (2000). Fishes on the Antarctic continental shelf: evolution of a marine species flock? Journal of Fish Biology, 57, 84-102. https://doi.org/10.1006/jfbi.2000.1604

Elith, J., Kearney, M., \& Phillips, S. (2010). The art of modelling range-shifting species. Methods in Ecology and Evolution, 1(4), 330-342.

Etourneau, J., Sgubin, G., Crosta, X., Swingedouw, D., Willmott, V., Barbara, L., ... Goosse, H. (2019). Ocean temperature impact on ice shelf extent in the eastern Antarctic Peninsula. Nature Communications, 10(1), 304.

Fabri-Ruiz, S., Danis, B., David, B., \& Saucède, T. (2018). Can we generate robust species distribution models at the scale of the Southern Ocean? Diversity and Distributions, $0(0), 1-17$. https://doi.org/10.1111/ddi.12835

This article is protected by copyright. All rights reserved 
Fabri-Ruiz, S., Saucède, T., Danis, B., \& David, B. (2017). Southern Ocean Echinoids database An updated version of Antarctic, Sub-Antarctic and cold temperate echinoid database. ZooKeys, (697), 1-20. https://doi.org/10.3897/zookeys.697.14746

Fabry, V. J., McClintock, J. B., Mathis, J. R., \& Grebmeier, J. M. (2009). Ocean Acidification at High Latitudes: Oceanography, 22(4), 160-171. Retrieved from JSTOR.

Fernandes, L., Day, J., Lewis, A., Slegers, S., Kerrigan, B., Breen, D., ... Stapleton, K. (2005). Establishing Representative No-Take Areas in the Great Barrier Reef: Large-Scale Implementation of Theory on Marine Protected Areas. Conservation Biology, 19(6), 1733-1744. https://doi.org/10.1111/j.1523-1739.2005.00302.x

Fischer, A., Bhakta, D., Macmillan-Lawler, M., \& Harris, P. (2019). Existing global marine protected area network is not representative or comprehensive measured against seafloor geomorphic features and benthic habitats. Ocean \& Coastal Management, 167, 176-187. https://doi.org/10.1016/j.ocecoaman.2018.10.001

Fraley, C., \& Raftery, A. E. (2006). MCLUST Version 3 for R: Normal Mixture Modeling and Model-Based Clustering. 57.

Franklin, J. (2010). Mapping species distributions: spatial inference and prediction. Cambridge University Press.

Fraser, C. I., Kay, G. M., Plessis, M. du, \& Ryan, P. G. (2017). Breaking down the barrier: dispersal across the Antarctic Polar Front. Ecography, 40(1), 235-237. https://doi.org/10.1111/ecog.02449

Fraser, C. I., Morrison, A. K., Hogg, A. M., Macaya, E. C., van Sebille, E., Ryan, P. G., ... Waters, J. M. (2018). Antarctica's ecological isolation will be broken by storm-driven dispersal and warming. Nature Climate Change, 8(8), 704-708. https://doi.org/10.1038/s41558-018-0209-7 Fredston-Hermann, A., Gaines, S. D., \& Halpern, B. S. (2018). Biogeographic constraints to marine conservation in a changing climate. Annals of the New York Academy of Sciences, 1429(1), 5-17. https://doi.org/10.1111/nyas.13597

Gallego, R., Dennis, T. E., Basher, Z., Lavery, S., \& Sewell, M. A. (2017). On the need to consider multiphasic sensitivity of marine organisms to climate change: a case study of the Antarctic acorn barnacle. Journal of Biogeography. https://doi.org/10.1111/jbi.13023 
Giovanelli, J. G. R., de Siqueira, M. F., Haddad, C. F. B., \& Alexandrino, J. (2010). Modeling a spatially restricted distribution in the Neotropics: How the size of calibration area affects the performance of five presence-only methods. Ecological Modelling, 221(2), 215-224. https://doi.org/10.1016/j.ecolmodel.2009.10.009

Goarant, A., Moteki, M., Hulley, P.-A., Causse, R., Dettai, A., Duhamel, G., ... Hosie, G. (2010). Estimating the biodiversity of the East Antarctic shelf and oceanic zone for ecoregionalisation: Example of the ichthyofauna of the CEAMARC (Collaborative East Antarctic Marine Census) CAML surveys. Polar Science, 4(2), 115-133. https://doi.org/10.1016/j.polar.2010.04.012

Gogina, M., Glockzin, M., \& Zettler, M. L. (2010). Distribution of benthic macrofaunal communities in the western Baltic Sea with regard to near-bottom environmental parameters. 1. Causal analysis. Journal of Marine Systems, 79(1-2), 112-123. https://doi.org/10.1016/j.jmarsys.2009.07.006

González-Wevar, C. A., Segovia, N. I., Rosenfeld, S., Ojeda, J., Hüne, M., Naretto, J., ... Poulin, E. (2018). Unexpected absence of island endemics: Long-distance dispersal in higher latitude subAntarctic Siphonaria (Gastropoda: Euthyneura) species. Journal of Biogeography, 45(4), 874884. https://doi.org/10.1111/jbi.13174

Government of South Georgia and the South Sandwich Islands. South Georgia and South Sandwich Islands Gazette. Marine Protected Areas Order 2019 (SR\&O No 1 of 2019). , (2019).

Grant, S. (2006). Bioregionalisation of the southern ocean: report of the Experts Workshop (Hobart, September 2006). Sydney: WWF-Australia Head Office.

Griffiths, H. J., Van de Putte, A., \& Danis, B. (2014). Data distribution: Patterns and implications. In Biogeographic atlas of the Southern Ocean. Cambridge, SCAR: Scientific Committee on Antarctic Research.

Griffiths, H.J., Barnes, D. K. A., \& Linse, K. (2009). Towards a generalized biogeography of the Southern Ocean benthos. Journal of Biogeography, 36(1), 162-177. https://doi.org/10.1111/j.1365-2699.2008.01979.x

Griffiths, H.J., Meijers, A. J. S., \& Bracegirdle, T. J. (2017). More losers than winners in a century of future Southern Ocean seafloor warming. Nature Climate Change, 7(10), 749-754. https://doi.org/10.1038/nclimate3377 
Grorud-Colvert, K., Claudet, J., Tissot, B. N., Caselle, J. E., Carr, M. H., Day, J. C., ... Malone, D. (2014). Marine protected area networks: assessing whether the whole is greater than the sum of its parts. PLoS One, 9(8), e102298.

Guillaumot, C., Artois, J., Saucède, T., Demoustier, L., Moreau, C., Eléaume, M., ... Danis, B. (2019). Broad-scale species distribution models applied to data-poor areas. Progress in Oceanography, 175, 198-207.

Guillaumot, C., Fabri-Ruiz, S., Martin, A., Eléaume, M., Danis, B., Féral, J.-P., \& Saucède, T. (2018). Benthic species of the Kerguelen Plateau show contrasting distribution shifts in response to environmental changes. Ecology and Evolution, 8(12), 6210-6225. https://doi.org/10.1002/ece3.4091

Gutt, J. (2001). On the direct impact of ice on marine benthic communities, a review. Polar Biology, 24(8), 553-564. https://doi.org/10.1007/s003000100262

Gutt, J., Bertler, N., Bracegirdle, T. J., Buschmann, A., Comiso, J., Hosie, G., ... Tournadre, J. (2015). The Southern Ocean ecosystem under multiple climate change stresses-an integrated circumpolar assessment. Global Change Biology, 21(4), 1434-1453.

Gutt, J., Isla, E., Bertler, A. N., Bodeker, G. E., Bracegirdle, T. J., Cavanagh, R. D., ... Xavier, J. C. (2017). Cross-disciplinarity in the advance of Antarctic ecosystem research. Marine Genomics, 37, 1-17. https://doi.org/10.1016/j.margen.2017.09.006

Gutt, J., Isla, E., Bertler, A. N., Bodeker, G. E., Bracegirdle, T. J., Cavanagh, R. D., .. Xavier, J. C. (2018). Cross-disciplinarity in the advance of Antarctic ecosystem research. Marine Genomics, 37, 1-17. https://doi.org/10.1016/j.margen.2017.09.006

Gutt, J., Bertler, N., Bracegirdle, T. J., Buschmann, A., Comiso, J., Hosie, G., ... Xavier, J. C. (2015). The Southern Ocean ecosystem under multiple climate change stresses - an integrated circumpolar assessment. Global Change Biology, 21(4), 1434-1453. https://doi.org/10.1111/gcb.12794

Hannah, L. (2008). Protected Areas and Climate Change. Annals of the New York Academy of Sciences, 1134(1), 201-212. https://doi.org/10.1196/annals.1439.009

Hannah, L., Midgley, G., Andelman, S., Araújo, M., Hughes, G., Martinez-Meyer, E., ... Williams, P. (2007). Protected area needs in a changing climate. Frontiers in Ecology and the 
Environment, 5(3), 131-138. https://doi.org/10.1890/1540-9295(2007)5[131:PANIAC]2.0.CO;2

Hardy, C., David, B., Rigaud, T., De Ridder, C., \& Saucède, T. (2011). Ectosymbiosis associated with cidaroids (Echinodermata: Echinoidea) promotes benthic colonization of the seafloor in the Larsen Embayments, Western Antarctica. Deep Sea Research Part II: Topical Studies in Oceanography, 58(1-2), 84-90. https://doi.org/10.1016/j.dsr2.2010.05.025

Hétérier, V., David, B., De Ridder, C., \& Rigaud, T. (2008). Ectosymbiosis is a critical factor in the local benthic biodiversity of the Antarctic deep sea. Marine Ecology Progress Series, 364, 6776. https://doi.org/10.3354/meps07487

Hill, N. A., Foster, S. D., Duhamel, G., Welsford, D., Koubbi, P., \& Johnson, C. R. (2017). Model-based mapping of assemblages for ecology and conservation management: A case study of demersal fish on the Kerguelen Plateau. Diversity and Distributions, 23(10), 1216-1230. https://doi.org/10.1111/ddi.12613

Hobbs, R. J., Valentine, L. E., Standish, R. J., \& Jackson, S. T. (2018). Movers and Stayers: Novel Assemblages in Changing Environments. Trends in Ecology \& Evolution, 33(2), 116-128. https://doi.org/10.1016/j.tree.2017.11.001

Hogg, O. T., Huvenne, V. A. I., Griffiths, H. J., \& Linse, K. (2018). On the ecological relevance of landscape mapping and its application in the spatial planning of very large marine protected areas. Science of The Total Environment, 626, 384-398. https://doi.org/10.1016/j.scitotenv.2018.01.009

Hunter, R. L., \& Halanych, K. M. (2008). Evaluating connectivity in the brooding brittle star Astrotoma agassizii across the Drake Passage in the Southern Ocean. Journal of Heredity, 99(2), $137-148$.

Ingels, J., Vanreusel, A., Brandt, A., Catarino, A. I., David, B., De Ridder, C., ... Robert, H. (2012). Possible effects of global environmental changes on Antarctic benthos: a synthesis across five major taxa. Ecology and Evolution, 2(2), 453-485. https://doi.org/10.1002/ece3.96

IPCC. (2018). Global Warming of $1.5^{\circ}$ C: An IPCC Special Report on the Impacts of Global Warming of $1.5^{\circ}$ C Above Pre-industrial Levels and Related Global Greenhouse Gas Emission Pathways, in the Context of Strengthening the Global Response to the Threat of Climate Change, Sustainable Development, and Efforts to Eradicate Poverty. Intergovernmental Panel on Climate 
Change.

Isaac, N. J., Turvey, S. T., Collen, B., Waterman, C., \& Baillie, J. E. (2007). Mammals on the EDGE: conservation priorities based on threat and phylogeny. PloS One, 2(3), e296.

Jacob, U., Terpstra, S., \& Brey, T. (2003). High-Antarctic regular sea urchins - the role of depth and feeding in niche separation. Polar Biology, 26(2), 99-104.

Jansen, J., Hill, N. A., Dunstan, P. K., McKinlay, J., Sumner, M. D., Post, A. L., ... Johnson, C. R. (2018). Abundance and richness of key Antarctic seafloor fauna correlates with modelled food availability. Nature Ecology \& Evolution, 2(1), 71-80. https://doi.org/10.1038/s41559-017-0392-3

Jones, M. C., \& Cheung, W. W. L. (2015). Multi-model ensemble projections of climate change effects on global marine biodiversity. ICES Journal of Marine Science, 72(3), 741-752. https://doi.org/10.1093/icesjms/fsu172

Kaiser, S., Barnes, D. K. A., \& Brandt, A. (2007). Slope and deep-sea abundance across scales: Southern Ocean isopods show how complex the deep sea can be. Deep Sea Research Part II: Topical Studies in Oceanography, 54(16-17), 1776-1789.

Kaiser, S., Brandão, S. N., Brix, S., Barnes, D. K. A., Bowden, D. A., Ingels, J., ... Badhe, R. (2013). Patterns, processes and vulnerability of Southern Ocean benthos: a decadal leap in knowledge and understanding. Marine Biology, 160(9), 2295-2317.

Kennicutt, M. C., Chown, S. L., Cassano, J. J., Liggett, D., Massom, R., Peck, L. S., ... others. (2014). Six priorities for Antarctic science. Nature, 512(7512), 23-25.

Kerr, R., Mata, M. M., Mendes, C. R. B., \& Secchi, E. R. (2018). Northern Antarctic Peninsula: a marine climate hotspot of rapid changes on ecosystems and ocean dynamics. Deep-Sea Res. Part II Top. Stud. Oceanogr, 149, 4-9.

Koubbi, P., Causse, R., Chazeau, C., Coste, G., Cotté, C., D’Ovidio, F., ... Gasco, N. (2016). Ecoregionalisation of the Kerguelen and Crozet islands oceanic zone. Part I: Introduction and Kerguelen oceanic zone. (p. 32). Paris.

Koubbi, P., Mignard, C., Causse, R., Da Silva, O., Baudena, A., Bost, C., ... Delord, K. (2016). Ecoregionalisation of the Kerguelen and Crozet islands oceanic zone. Part II: The Crozet oceanic zone (p. 50).

Koubbi, P., Moteki, M., Duhamel, G., Goarant, A., Hulley, P.-A., O’Driscoll, R., ... Hosie, G. 
(2011). Ecoregionalization of myctophid fish in the Indian sector of the Southern Ocean: Results from generalized dissimilarity models. Deep Sea Research Part II: Topical Studies in Oceanography, 58(1-2), 170-180. https://doi.org/10.1016/j.dsr2.2010.09.007

Kuhn, M. (2012). The caret package. R Foundation for Statistical Computing, Vienna, Austria. URL Https://Cran. r-Project. Org/Package= Caret.

Lawler, J. J., White, D., Sifneos, J. C., \& Master, L. L. (2003). Rare Species and the Use of Indicator Groups for Conservation Planning. Conservation Biology, 17(3), 875-882. https://doi.org/10.1046/j.1523-1739.2003.01638.x

Le Guen, C., Kato, A., Raymond, B., Barbraud, C., Beaulieu, M., Bost, C.-A., ... Ropert-Coudert, Y. (2018). Reproductive performance and diving behaviour share a common sea-ice concentration optimum in Adélie penguins (Pygoscelis adeliae). Global Change Biology. https://doi.org/10.1111/gcb.14377

Lecointre, G., Améziane, N., Boisselier, M.-C., Bonillo, C., Busson, F., Causse, R., .. Cruaud, C. (2013). Is the species flock concept operational? The Antarctic shelf case. PloS One, 8(8), e68787.

Legendre, P. (1993). Spatial Autocorrelation: Trouble or New Paradigm? Ecology, 74(6), 16591673. https://doi.org/10.2307/1939924

Lenihan, H. S., \& Oliver, J. S. (1995). Anthropogenic and natural disturbances to marine benthic communities in Antarctica. Ecological Applications, 311-326.

Leroy, B., Meynard, C. N., Bellard, C., \& Courchamp, F. (2016). virtualspecies, an R package to generate virtual species distributions. Ecography, 39(6), 599-607. https://doi.org/10.1111/ecog.01388

Lindegren, M., Holt, B. G., MacKenzie, B. R., \& Rahbek, C. (2018). A global mismatch in the protection of multiple marine biodiversity components and ecosystem services. Scientific Reports, 8(1), 4099. https://doi.org/10.1038/s41598-018-22419-1

Linse, K., Griffiths, H. J., Barnes, D. K. A., \& Clarke, A. (2006). Biodiversity and biogeography of Antarctic and sub-Antarctic mollusca. Deep Sea Research Part II: Topical Studies in Oceanography, 53(8-10), 985-1008. https://doi.org/10.1016/j.dsr2.2006.05.003

Linse, K., Walker, L. J., \& Barnes, D. K. A. (2008). Biodiversity of echinoids and their epibionts around the Scotia Arc, Antarctica. Antarctic Science, 20(03). 
https://doi.org/10.1017/S0954102008001181

Lister, K. N., Lamare, M. D., \& Burritt, D. J. (2010). Sea ice protects the embryos of the Antarctic sea urchin Sterechinus neumayeri from oxidative damage due to naturally enhanced levels of UVB radiation. Journal of Experimental Biology, 213(11), 1967-1975. https://doi.org/10.1242/jeb.039990

Lohrer, A. M., Cummings, V. J., \& Thrush, S. F. (2013). Altered Sea Ice Thickness and Permanence Affects Benthic Ecosystem Functioning in Coastal Antarctica. Ecosystems, 16(2), 224-236. https://doi.org/10.1007/s10021-012-9610-7

Lombard, A. T., Reyers, B., Schonegevel, L. Y., Cooper, J., Smith-Adao, L. B., Nel, D. C., ... Tosh, C. A. (2007). Conserving pattern and process in the Southern Ocean: designing a marine protected area for the Prince Edward Islands. Antarctic Science, 19(1), 39-54.

Longhurst, A. R. (2007). Ecological geography of the sea (2nd ed). Elsevier.

Loots, C., Koubbi, P., \& Duhamel, G. (2007). Habitat modelling of Electrona antarctica (Myctophidae, Pisces) in Kerguelen by generalized additive models and geographic information systems. Polar Biology, 30(8), 951-959. https://doi.org/10.1007/s00300-007-0253-7

Lotze, H. K., Tittensor, D. P., Bryndum-Buchholz, A., Eddy, T. D., Cheung, W. W., Galbraith, E. D., ... Blanchard, J. L. (2019). Global ensemble projections reveal trophic amplification of ocean biomass declines with climate change. Proceedings of the National Academy of Sciences, 116(26), $12907-12912$.

Margules, C. R., \& Pressey, R. L. (2000). Systematic conservation planning. Nature, 405(6783), 243.

McArthur, M. A., Brooke, B. P., Przeslawski, R., Ryan, D. A., Lucieer, V. L., Nichol, S., ... Radke, L. C. (2010). On the use of abiotic surrogates to describe marine benthic biodiversity. Estuarine, Coastal and Shelf Science, 88(1), 21-32. https://doi.org/10.1016/j.ecss.2010.03.003

McLeod, E., Salm, R., Green, A., \& Almany, J. (2009). Designing marine protected area networks to address the impacts of climate change. Frontiers in Ecology and the Environment, 7(7), 362370. https://doi.org/10.1890/070211

Meijers, A. J. S., Shuckburgh, E., Bruneau, N., Sallee, J.-B., Bracegirdle, T. J., \& Wang, Z. (2012). Representation of the Antarctic Circumpolar Current in the CMIP5 climate models and 
future changes under warming scenarios. Journal of Geophysical Research: Oceans, 117(C12), 138. https://doi.org/10.1029/2012JC008412

Menezes, V. V., Macdonald, A. M., \& Schatzman, C. (2017). Accelerated freshening of Antarctic Bottom Water over the last decade in the Southern Indian Ocean. Science Advances, 3(1), e1601426.

Meredith, M. P., \& King, J. C. (2005). Rapid climate change in the ocean west of the Antarctic Peninsula during the second half of the 20th century. Geophysical Research Letters, 32(19), L19604. https://doi.org/10.1029/2005GL024042

Michel, L. N., David, B., Dubois, P., Lepoint, G., \& De Ridder, C. (2016). Trophic plasticity of Antarctic echinoids under contrasted environmental conditions. Polar Biology, 39(5), 913-923. https://doi.org/10.1007/s00300-015-1873-y

Moon, K. L., Chown, S. L., \& Fraser, C. I. (2017). Reconsidering connectivity in the subAntarctic. Biological Reviews, 92(4), 2164-2181. https://doi.org/10.1111/brv.12327

Mora, C., \& Sale, P. (2011). Ongoing global biodiversity loss and the need to move beyond protected areas: a review of the technical and practical shortcomings of protected areas on land and sea. Marine Ecology Progress Series, 434, 251-266. https://doi.org/10.3354/meps09214

Moreau, C., Saucède, T., Jossart, Q., Agüera, A., Brayard, A., \& Danis, B. (2017). Reproductive strategy as a piece of the biogeographic puzzle: a case study using Antarctic sea stars (Echinodermata, Asteroidea). Journal of Biogeography, 44(4), 848-860. https://doi.org/10.1111/jbi.12965

Moya, F., Saucede, T., \& Manjón-Cabeza, M. E. (2012). Environmental control on the structure of echinoid assemblages in the Bellingshausen Sea (Antarctica). Polar Biology, 35(9), 1343-1357.

Nachtsheim, D. A., Jerosch, K., Hagen, W., Plötz, J., \& Bornemann, H. (2017). Habitat modelling of crabeater seals (Lobodon carcinophaga) in the Weddell Sea using the multivariate approach Maxent. Polar Biology, 40(5), 961-976.

Orsi, A. H., Whitworth, T., \& Nowlin, W. D. (1995). On the meridional extent and fronts of the Antarctic Circumpolar Current. Deep Sea Research Part I: Oceanographic Research Papers, 42(5), 641-673. https://doi.org/10.1016/0967-0637(95)00021-W

Paradis, E., Strimmer, K., Claude, J., Jobb, G., Opgen-Rhein, R., Dutheil, J., ... Lemon, J. (2008). 
The ape package. Analyses of Phylogenetics and Evolution.

Pearse, J. S., Mooi, R., Lockhart, S. J., \& Brandt, A. (2009). Brooding and Species Diversity in the Southern Ocean: Selection for Brooders or Speciation within Brooding Clades? In Smithsonian at the poles: contributions to International Polar Year science (pp. 181-196). https://doi.org/10.5479/si.097884601X.0

Peck, L. (2005). Prospects for surviving climate change in Antarctic aquatic species. Frontiers in Zoology, 2(1), 9 .

Peck, L. (2016). A cold limit to adaptation in the sea. Trends in Ecology \& Evolution, 31(1), 1326.

Peck, L. (2018). Antarctic marine biodiversity: adaptations, environments and responses to change. In S. J. Hawkins, A. J. Evans, A. C. Dale, L. B. Firth, \& I. P. Smith, Oceanography and Marine Biology: An Annual Review. Retrieved from https://books.google.fr/books?id=QouADwAAQBAJ

Peck, L., Morley, S. A., \& Clark, M. S. (2010). Poor acclimation capacities in Antarctic marine ectotherms. Marine Biology, 157(9), 2051-2059. https://doi.org/10.1007/s00227-010-1473-x

Peck, L., Webb, K. E., \& Bailey, D. M. (2004). Extreme sensitivity of biological function to temperature in Antarctic marine species. Functional Ecology, 18(5), 625-630. https://doi.org/10.1111/j.0269-8463.2004.00903.x

Pierrat, B., Saucède, T., Brayard, A., \& David, B. (2013). Comparative biogeography of echinoids, bivalves and gastropods from the Southern Ocean. Journal of Biogeography, 40(7), 1374-1385. https://doi.org/10.1111/jbi.12088

Pierrat, B., Saucède, T., Laffont, R., De Ridder, C., Festeau, A., \& David, B. (2012). Large-scale distribution analysis of Antarctic echinoids using ecological niche modelling. Marine Ecology Progress Series, 463, 215-230. https://doi.org/10.3354/meps09842

Pinkerton, M. H., Smith, A. N. H., Raymond, B., Hosie, G. W., Sharp, B., Leathwick, J. R., \& Bradford-Grieve, J. M. (2010). Spatial and seasonal distribution of adult Oithona similis in the Southern Ocean: Predictions using boosted regression trees. Deep Sea Research Part I: Oceanographic Research Papers, 57(4), 469-485. https://doi.org/10.1016/j.dsr.2009.12.010

Portner, H. O., Peck, L., \& Somero, G. (2007). Thermal limits and adaptation in marine Antarctic 
ectotherms: an integrative view. Philosophical Transactions of the Royal Society B: Biological Sciences, 362(1488), 2233-2258. https://doi.org/10.1098/rstb.2006.1947

Poulin, E., \& Féral, J.-P. (1996). Why are there so many species of brooding Antarctic echinoids? Evolution, 50(2), 820-830.

Purkey, S. G., \& Johnson, G. C. (2013). Antarctic Bottom Water Warming and Freshening: Contributions to Sea Level Rise, Ocean Freshwater Budgets, and Global Heat Gain. Journal of Climate, 26(16), 6105-6122. https://doi.org/10.1175/JCLI-D-12-00834.1

Rees, M. J., Jordan, A., Price, O. F., Coleman, M. A., \& Davis, A. R. (2014). Abiotic surrogates for temperate rocky reef biodiversity: implications for marine protected areas. Diversity and Distributions, 20(3), 284-296. https://doi.org/10.1111/ddi.12134

Rees, S. E., Pittman, S. J., Foster, N., Langmead, O., Griffiths, C., Fletcher, S., ... Attrill, M. (2018). Bridging the divide: Social-ecological coherence in Marine Protected Area network design. Aquatic Conservation: Marine and Freshwater Ecosystems, 28(3), 754-763.

Reiss, H., Cunze, S., König, K., Neumann, H., \& Kröncke, I. (2011). Species distribution modelling of marine benthos: a North Sea case study. Marine Ecology Progress Series, 442, 7186. https://doi.org/10.3354/meps09391

Reygondeau, G., \& Huettmann, F. (2014). Past, present and future state of pelagic habitats in the Antarctic Ocean. In Biogeographic atlas of the Southern Ocean. Cambridge, SCAR: Scientific Committee on Antarctic Research.

Reygondeau, G., Longhurst, A., Martinez, E., Beaugrand, G., Antoine, D., \& Maury, O. (2013). Dynamic biogeochemical provinces in the global ocean: Dynamic Biogeochemical provinces. Global Biogeochemical Cycles, 27(4), 1046-1058. https://doi.org/10.1002/gbc.20089

Roberts, C. M., Branch, G., Bustamante, R. H., Castilla, J. C., Dugan, J., Halpern, B. S., ... Warner, R. R. (2003). Application of Ecological Criteria in Selecting Marine Reserves and Developing Reserve Networks. Ecological Applications, 13(sp1), 215-228. https://doi.org/10.1890/1051-0761(2003)013[0215:AOECIS]2.0.CO;2

Roberts, C. M., O’Leary, B. C., McCauley, D. J., Cury, P. M., Duarte, C. M., Lubchenco, J., ... Castilla, J. C. (2017). Marine reserves can mitigate and promote adaptation to climate change. Proceedings of the National Academy of Sciences, 114(24), 6167-6175. 
https://doi.org/10.1073/pnas.1701262114

Rogers, A. D., Frinault, B. A. V., Barnes, D. K. A., Bindoff, N. L., Downie, R., Ducklow, H. W., ... Wright, R. (2020). Antarctic Futures: An Assessment of Climate-Driven Changes in Ecosystem Structure, Function, and Service Provisioning in the Southern Ocean. Annual Review of Marine Science, 12(1), annurev-marine-010419-011028. https://doi.org/10.1146/annurev-marine-010419011028

Saucède, T., Guillaumot, C., Michel, L., Fabri-Ruiz, S., Bazin, A., Cabessut, M., ... De Ridder, C. (2017). Modelling species response to climate change in sub-Antarctic islands: echinoids as a case study for the Kerguelen Plateau.

Saucède, T., Pierrat, B., Brayard, A., \& David, B. (2013). Palaeobiogeography of Austral echinoid faunas: a first quantitative approach. Geological Society, London, Special Publications, 381(1), $117-127$.

Saucède, T., Pierrat, B., \& David, B. (2014). Echinoids. In Biogeographic atlas of the Southern Ocean (pp. 213-220). Cambridge, SCAR: Scientific Committee on Antarctic Research.

Schmidtko, S., Heywood, K. J., Thompson, A. F., \& Aoki, S. (2014). Multidecadal warming of Antarctic waters. Science, 346(6214), 1227-1231. https://doi.org/10.1126/science.1256117

Scott, J. (2019, August 8). Retrieved from NOAA's Climate Change Web Portal website: https://www.esrl.noaa.gov/psd/ipcc/ocn/

Scrucca, L., Fop, M., Murphy, T. B., \& Raftery, A. E. (2016). mclust 5: Clustering, Classification and Density Estimation Using Gaussian Finite Mixture Models. 50.

Sen Gupta, A., Santoso, A., Taschetto, A. S., Ummenhofer, C. C., Trevena, J., \& England, M. H. (2009). Projected Changes to the Southern Hemisphere Ocean and Sea Ice in the IPCC AR4 Climate Models. Journal of Climate, 22(11), 3047-3078. https://doi.org/10.1175/2008JCLI2827.1

Sewell, M. A., \& Hofmann, G. E. (2011). Antarctic echinoids and climate change: a major impact on the brooding forms. Global Change Biology, 17(2), 734-744.

Shanks, A. L., Grantham, B. A., \& Carr, M. H. (2003). Propagule Dispersal Distance and the Size and Spacing of Marine Reserves. Ecological Applications, 13(sp1), 159-169. https://doi.org/10.1890/1051-0761(2003)013[0159:PDDATS]2.0.CO;2

Siegert, M. J., Rumble, J., Atkinson, A., Rogelj, J., Edwards, T., Davies, B. J., ... Stroeve, J. 
(2019). The Antarctic Peninsula under a $1.5^{\circ} \mathrm{C}$ global warming scenario. Frontiers in Environmental Science, 7, 102.

Smith, W. H., \& Sandwell, D. T. (1997). Global sea floor topography from satellite altimetry and ship depth soundings. Science, 277(5334), 1956-1962.

Spalding, M. D., Fox, H. E., Allen, G. R., Davidson, N., Ferdana, Z. A., Finlayson, M. A. X., ... Lourie, S. A. (2007). Marine ecoregions of the world: a bioregionalization of coastal and shelf areas. BioScience, 57(7), 573-583.

Spalding, M. D., Fox, H. E., Allen, G. R., Davidson, N., Ferdaña, Z. A., Finlayson, M., ... Robertson, J. (2007). Marine Ecoregions of the World: A Bioregionalization of Coastal and Shelf Areas. BioScience, 57(7), 573-583. https://doi.org/10.1641/B570707

Teschke, K., Bornemann, H., Bombosch, A., Brey, T., Brtnik, P., Burkhardt, E., ... Gutt, J. (2013). Progress report on the scientific data compilation and analyses in support of the development of a CCAMLR MPA in the Weddell Sea (Antarctica). SC-CAMLR-XXXII, (BG/07), $1-29$.

Thiers, L., Delord, K., Bost, C.-A., Guinet, C., \& Weimerskirch, H. (2017). Important marine sectors for the top predator community around Kerguelen Archipelago. Polar Biology, 40(2), 365378. https://doi.org/10.1007/s00300-016-1964-4

Thuiller, W., Lafourcade, B., Engler, R., \& Araújo, M. B. (2009). BIOMOD - a platform for ensemble forecasting of species distributions. Ecography, 32(3), 369-373. https://doi.org/10.1111/j.1600-0587.2008.05742.x

Turner, J., Barrand, N. E., Bracegirdle, T. J., Convey, P., Hodgson, D. A., Jarvis, M., ... Klepikov, A. (2014). Antarctic climate change and the environment: an update. Polar Record, 50(03), 237259. https://doi.org/10.1017/S0032247413000296

Turner, J., Bindschadler, R., Convey, P., DiPrisco, G., Fahrbach, E., Gutt, J., ... Summerhayes, C. (2009). Antarctic climate change and the environment: [a contribution to the International Polar Year 2007 - 2008]. Cambridge: Scientific Committee on Antarctic Research.

Turner, J., \& Comiso, J. (2017). Solve Antarctica's sea-ice puzzle. Nature News, 547(7663), 275.

Villamor, A., \& Becerro, M. A. (2012). Species, trophic, and functional diversity in marine protected and non-protected areas. Journal of Sea Research, 73, 109-116. 
Wenzel, L., Gilbert, N., Goldsworthy, L., Tesar, C., Mcconnell, M., \& Okter, M. (2016). Polar opposites? Marine conservation tools and experiences in the changing Arctic and Antarctic. Aquatic Conservation: Marine and Freshwater Ecosystems, 26(S2), 61-84. https://doi.org/10.1002/aqc.2649

Williams, A., Bax, N. J., Kloser, R. J., Althaus, F., Barker, B., \& Keith, G. (2018). Australia's deep-water reserve network: implications of false homogeneity for classifying abiotic surrogates of biodiversity. 11.

Worm, B., Hilborn, R., Baum, J. K., Branch, T. A., Collie, J. S., Costello, C., ... Jennings, S. (2009). Rebuilding global fisheries. Science, 325(5940), 578-585.

Xavier, J. C., Raymond, B., Jones, D. C., \& Griffiths, H. (2016). Biogeography of cephalopods in the Southern Ocean using habitat suitability prediction models. Ecosystems, 19(2), 220-247. 


\begin{tabular}{|c|c|c|c|c|c|c|c|c|c|c|c|c|c|}
\hline & Ecoregion \#1 & ...\#2 & $\ldots \# 3$ & $\# 4$ & $\# 5$ & $\# 6$ & $\# 7$ & $\# 8$ & $\# 9$ & $\# 10$ & $\# 11$ & $\# 12$ & Total \\
\hline surface area $\left(\mathbf{k m}^{2}\right)$ & 882354 & 867315 & 490934 & 366288 & 210892 & 497349 & 710385 & 893029 & 1078172 & 359016 & 433701 & 333104 & 7122540 \\
\hline$\%$ total surface area & 12 & 12 & 7 & 5 & 3 & 7 & 10 & 13 & 15 & 5 & 6 & 5 & 100 \\
\hline $\begin{array}{l}\text { Surface in current MPAs } \\
\qquad\left(\mathbf{k m}^{2}\right)\end{array}$ & 168195 & 106814 & 104374 & 55458 & 149781 & 135562 & 134790 & 425769 & 191062 & 46250 & 38183 & 301 & 1556539 \\
\hline $\begin{array}{l}\text { Surface in all MPAs } \\
\qquad\left(\mathbf{k m}^{2}\right)\end{array}$ & 578463 & 615487 & 215556 & 208243 & 201242 & 156222 & 160901 & 461821 & 263219 & 46250 & 38183 & 301 & 2945887 \\
\hline $\begin{array}{c}\% \text { of surface in current } \\
\text { MPAs }\end{array}$ & 19,06 & 12,32 & 21,26 & 15,14 & 71,02 & 27,26 & 18,97 & 47,68 & 17,72 & 12,88 & 8,80 & 0,09 & 21,85 \\
\hline$\%$ of surface in all MPAs & 65,56 & 70,96 & 43,91 & 56,85 & 95,42 & 31,41 & 22,65 & 51,71 & 24,41 & 12,88 & 8,80 & 0,09 & 41,36 \\
\hline $\begin{array}{c}\text { contribution to current } \\
\text { MPAs in \% }\end{array}$ & 3,14 & 1,99 & 1,95 & 1,03 & 2,79 & 2,53 & 2,51 & 7,94 & 3,56 & 0,86 & 0,71 & 0,01 & 29,0 \\
\hline $\begin{array}{c}\text { contribution to all MPAs } \\
\text { in } \%\end{array}$ & 4,97 & 5,29 & 1,85 & 1,79 & 1,73 & 1,34 & 1,38 & 3,97 & 2,26 & 0,40 & 0,33 & 0,00 & 25,3 \\
\hline $\begin{array}{c}\text { Island surface area } \\
\text { included in ecoregions } \\
\left(\mathrm{km}^{2}\right)\end{array}$ & 0 & 435 & 0 & 0 & 0 & 0 & 0 & 620307 & 110113 & 35494 & 425393 & 333104 & 1524845 \\
\hline $\begin{array}{c}\% \text { island surface } \\
\text { included in ecoregions }\end{array}$ & 0,00 & 0,05 & 0,00 & 0,00 & 0,00 & 0,00 & 0,00 & 69,46 & 10,21 & 9,89 & 98,08 & 100,00 & \\
\hline
\end{tabular}

Table 1: Ecoregion surface areas, proportion of ecoregions included in acted and proposed MPAs, contribution of ecoregions to MPAs (proportion of MPAs covered with ecoregions) and part of oceanic islands included in ecoregions.

This article is protected by copyright. All rights reserved 


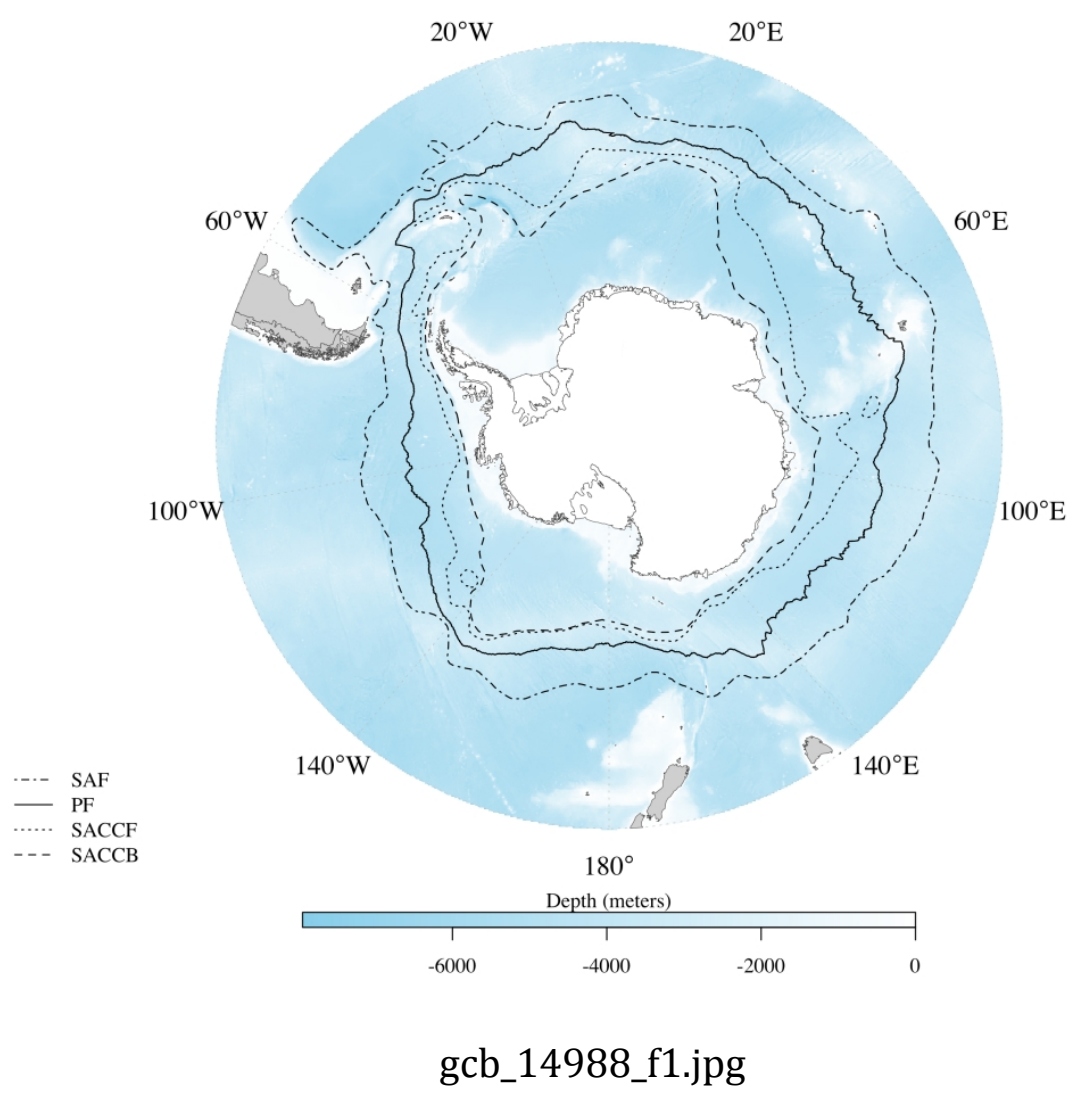

This article is protected by copyright. All rights reserved 


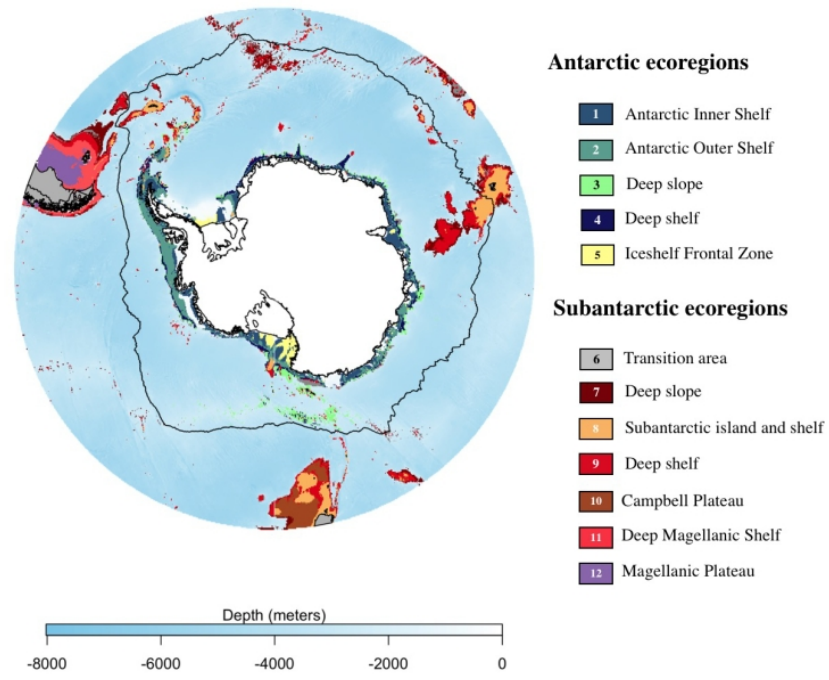

gcb_14988_f2.jpg

This article is protected by copyright. All rights reserved 


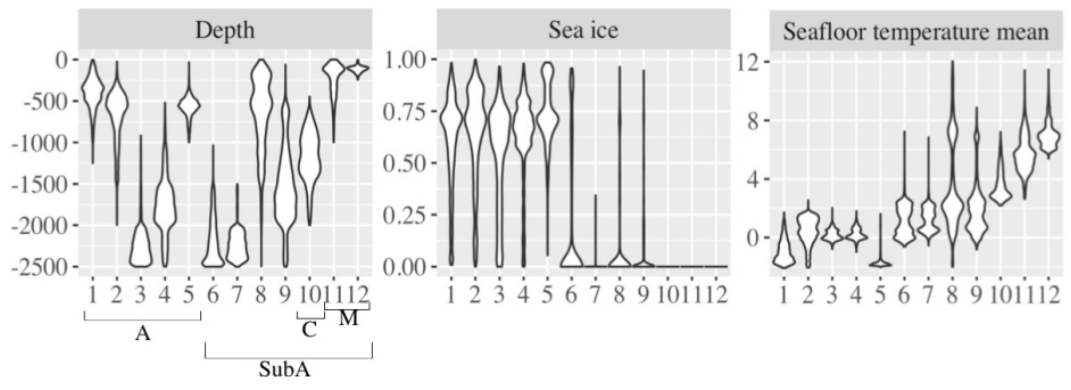

gcb_14988_f3.jpg

This article is protected by copyright. All rights reserved 


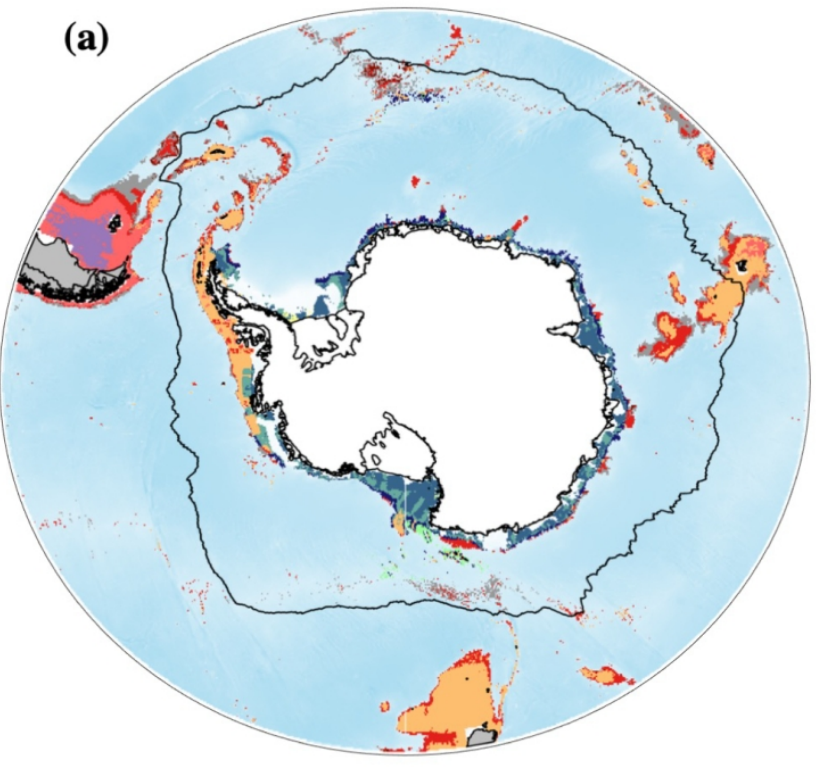

\section{Antarctic ecoregions}

1 East Antarctic shelf

2 Circum-Antarctic Plateau

3 Deep slope

4 Deep shelf

5 High Antarctic shelf

\section{Subantarctic ecoregions}

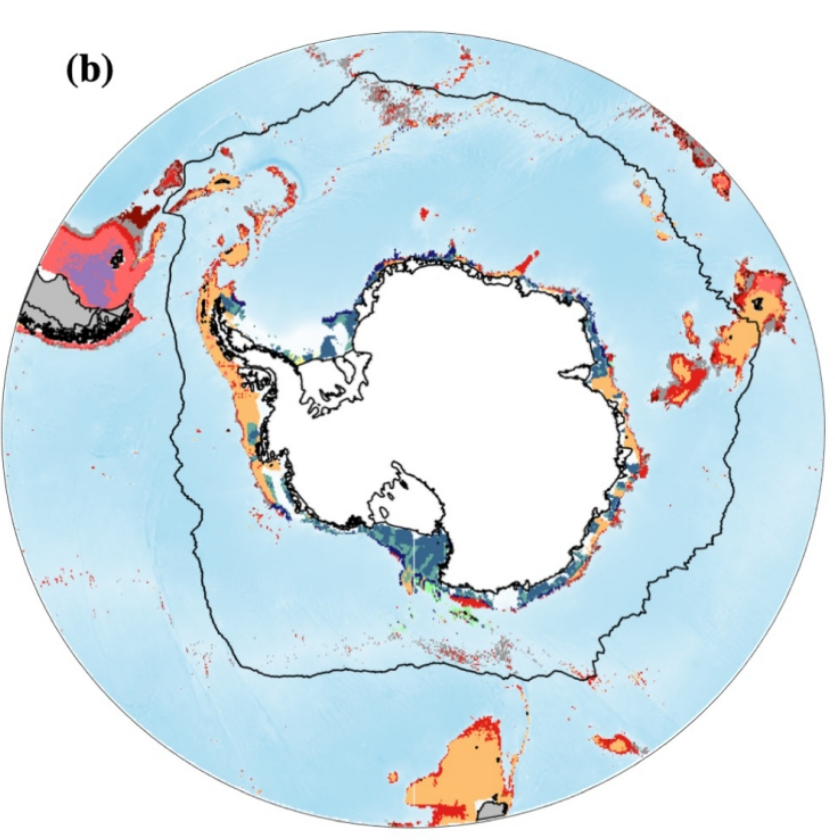

6 Transition area

7 Deep slope

8 Subantarctic island and shelf

9 Deep shelf

10 Campbell Plateau

11 Deep Magellanic Shelf

12 Magellanic Plateau

gcb_14988_f4.jpg

This article is protected by copyright. All rights reserved 
a)
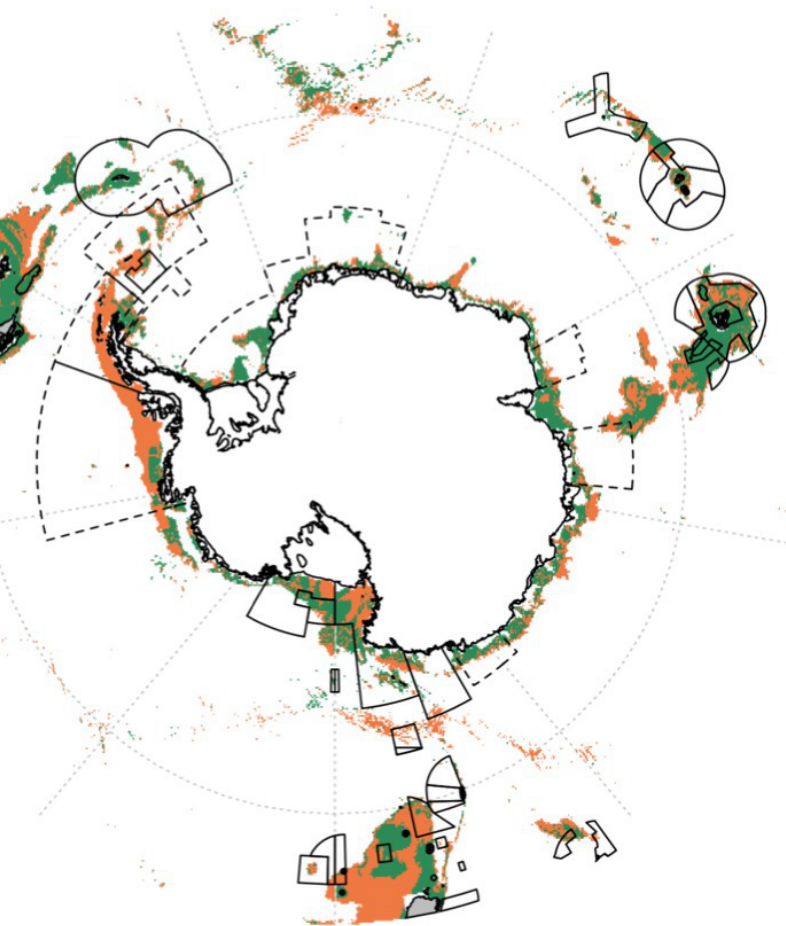

c)
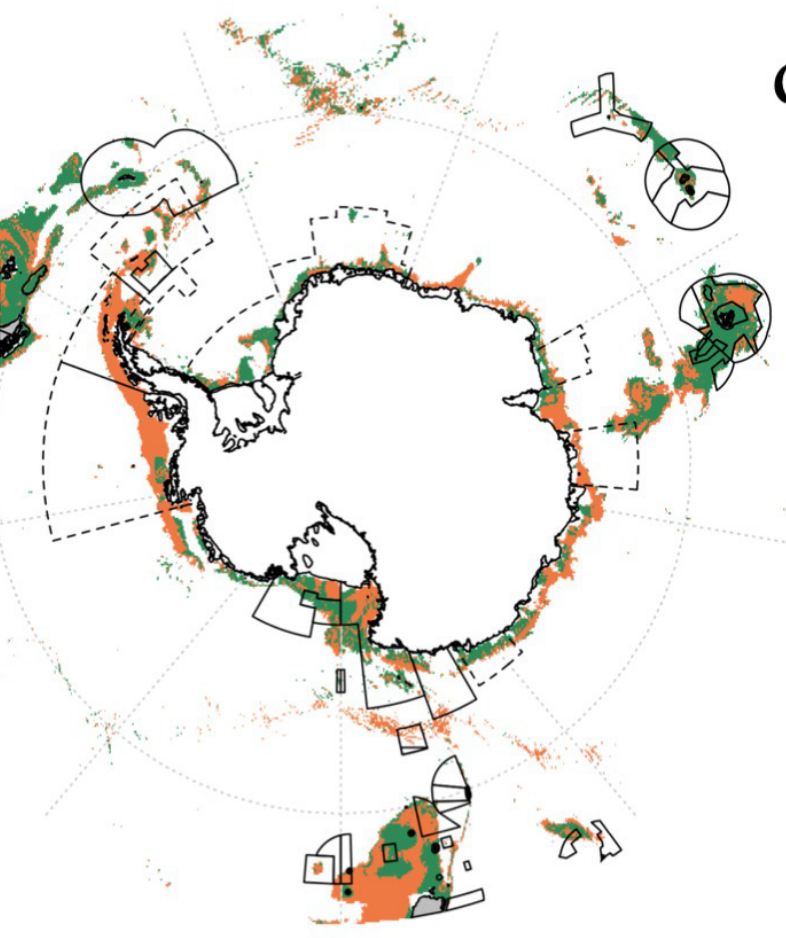

on

b)

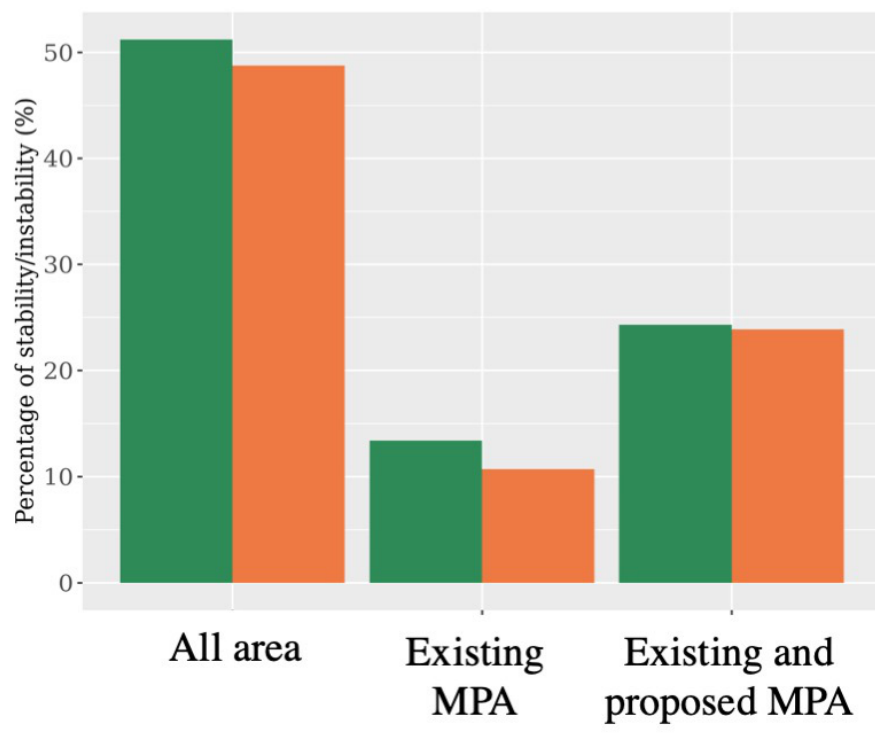

d)

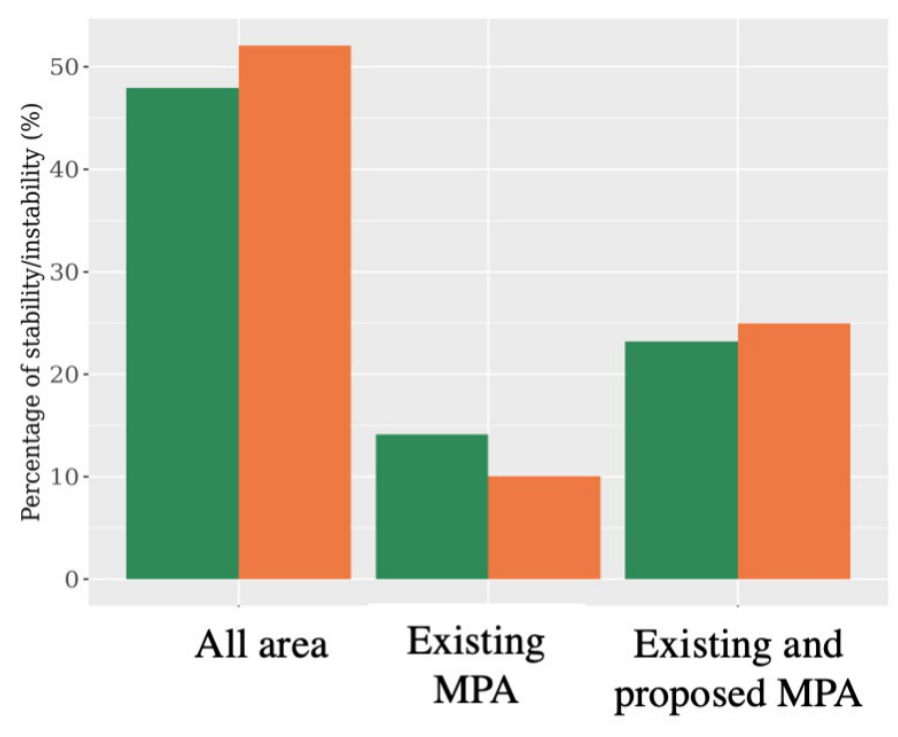

$\square$ Stable $\square$ Unstable 

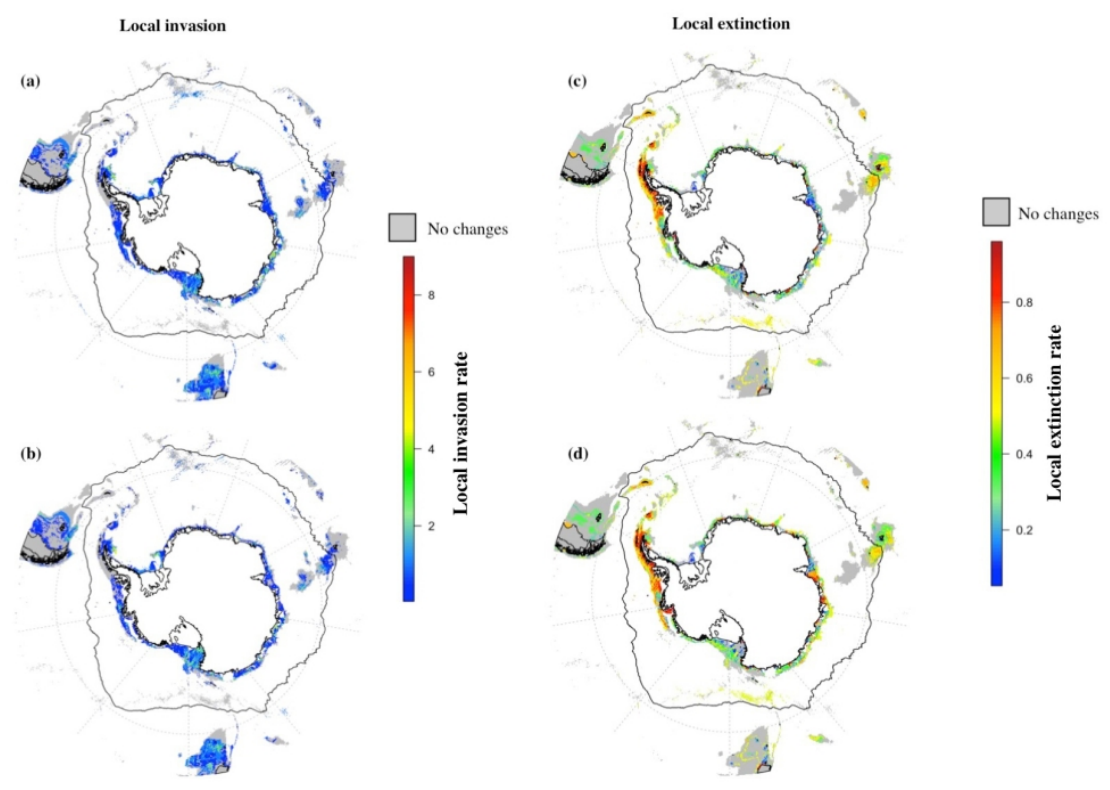

gcb_14988_f6.jpg

This article is protected by copyright. All rights reserved 


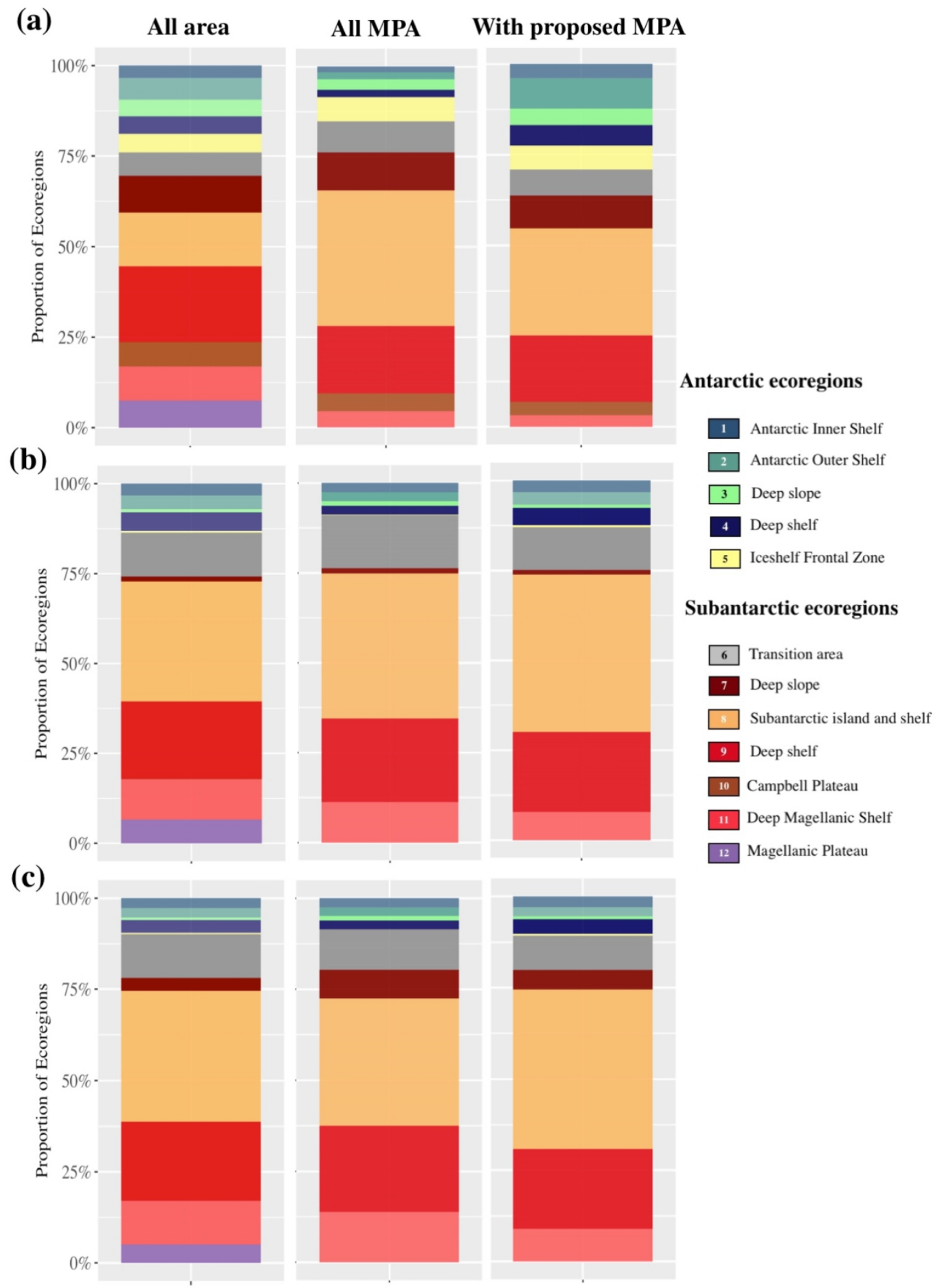

gcb_14988_f7.jpg

This article is protected by copyright. All rights reserved 